\title{
EFFECT OF OPERATING CONDITIONS ON THE PRODUCTION OF VOLATILE FATTY ACIDS FROM ORGANIC WASTES
}

by

\author{
Daniel Battaglia \\ B.Eng., Ryerson University, 2017
}

\author{
A MRP \\ presented to Ryerson University \\ in partial fulfillment of the \\ requirements for the degree of \\ Master of Engineering \\ in the Program of \\ Civil Engineering
}

Toronto, Ontario, Canada, 2019

(C) Daniel Battaglia, 2019 


\section{Authors Declaration}

I hereby declare that I am the sole author of this MRP. This is a true copy of the MRP, including any required final revisions.

I authorize Ryerson University to lend this MRP to other institutions or individuals for the purpose of scholarly research.

I further authorize Ryerson University to reproduce this MRP by photocopying or by other means, in total or in part, at the request of other institutions or individuals for the purpose of scholarly research.

I understand that my MRP may be made electronically available to the public. 


\title{
Effect of Operating Conditions on the Production of Volatile Fatty Acids from Organic Wastes
}

\author{
B.Eng., Ryerson University, 2017
}

Daniel Battaglia

Master of Engineering, Ryerson University

\begin{abstract}
The five parameters being analyzed are $\mathrm{pH}$, temperature, retention time/organic loading rate, substrate to inoculum ratio, and inhibitors of VFAs. The effect of $\mathrm{pH}$ has been shown to produce optimal concentrations of VFAs when outside the optimal range of methanogenesis. Temperature sees different types of VFAs being produced at different concentrations dependant on mesophilic or thermophilic conditions. The organic loading rate (OLR) and retention time (RT) demonstrate similar concepts as longer periods of time allow for more VFAs to be converted from the waste but readily supplying waste to digesters sees higher concentrations produced immediately. The substrate to inoculum ratio (S/I) showed ratios above 1 to be favorable in production as it provided enough inoculum (microorganisms) to convert VFAs effectively. Lastly, the effects of several VFA inhibitors are discussed with regards to their impacts on the anaerobic digestion process and their inhibition of certain VFA's formation.
\end{abstract}




\section{Acknowledgements}

I would like to thank Ryerson University and the Yeates School of Graduate Studies for giving me the opportunity to pursue a Graduate Degree.

I would like to thank Dr. Elsayed Elbeshbishy and Ehssan Hosseini Koupaie for guiding me through the process of writing this MRP.

I would like to express my sincere gratitude and thanks to Dr. Elsayed Elbeshbishy for being my supervisor throughout the course of this graduate degree. He has provided guidance, knowledge, and assistance whenever I needed it and has been an influential person in my graduate degree studies. 


\section{Dedication}

To my loving family, friends, and Angelica,

who have always supported me

throughout my life's endeavors. 


\section{Table of Contents}

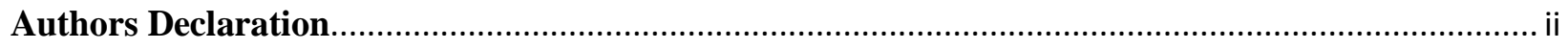

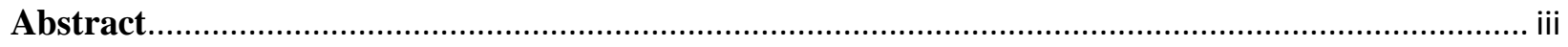

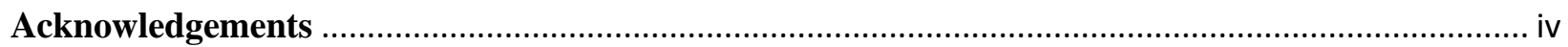

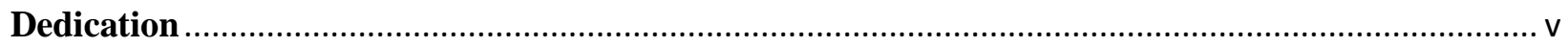

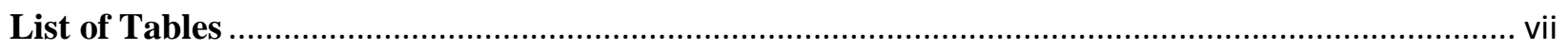

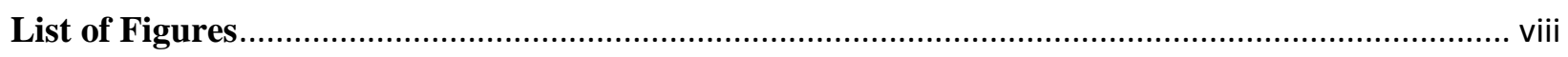

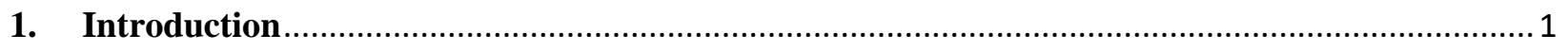

1.1 Importance of a Circular Economy …........................................................................... 1

1.2 What are VFAs and how are they produced ................................................................. 3

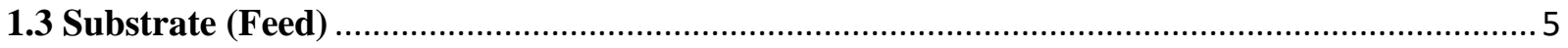

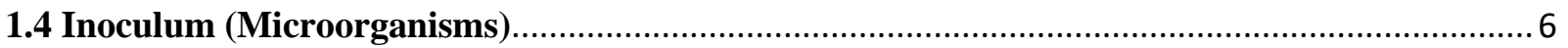

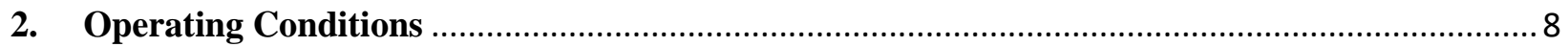

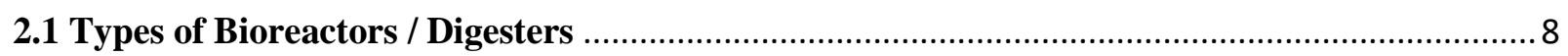

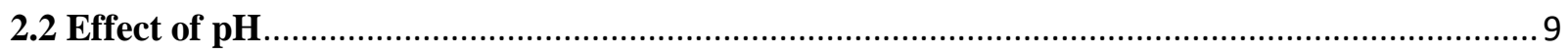

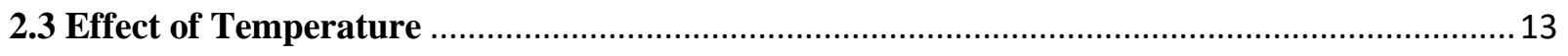

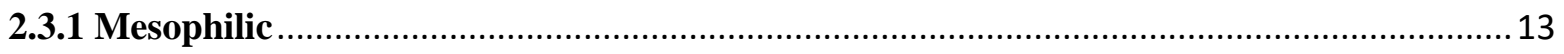

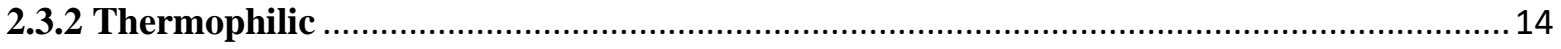

2.4 Effect of Retention Time / Organic Loading Rate ….......................................................... 19

2.5 Effects of Substrate to Inoculum Ratio (Food to Microorganism) ..........................................2 24

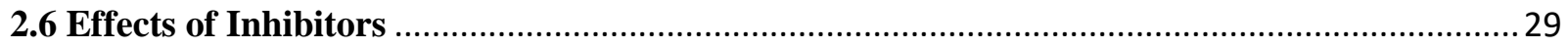

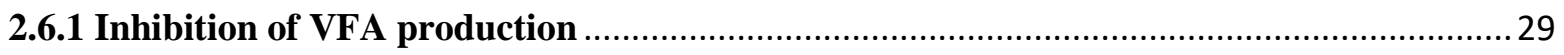

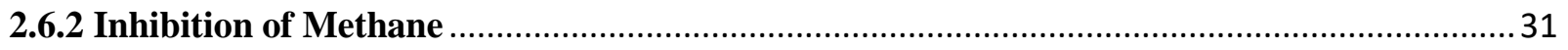

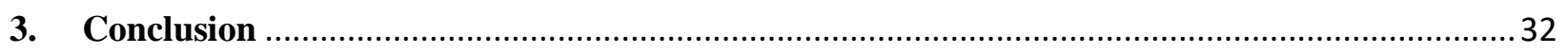

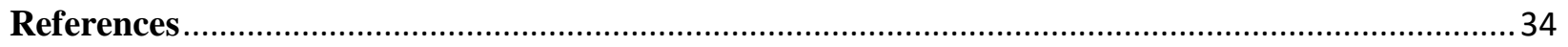




\section{List of Tables}

\section{Description}

Table 1: Compilation: Effect of $\mathrm{pH}$

Table 2: Compilation: Effect of Temperature

Table 3: Compilation: Effect of OLR and RT

Table 4: Compilation: Effect of S/I Ratio

Table 5: Compilation: Effect of Inhibitors

\section{Page Number}

10

17

21

26

30 


\section{List of Figures}

\section{Description}

Figure 1: Circular Economy

Figure 2: Four stages of biogas production

Figure 3: Effect of $\mathrm{pH}$ and RT on VFA production

Figure 4: Mesophilic and Thermophilic VFA concentrations

Figure 5: VFA concentrations for 12-day RT

Figure 6: VFA production for varying S/I ratios
Page Number

1

4

11

16

20

27 


\section{Introduction}

\subsection{Importance of a Circular Economy}

As the world shifts towards a more environmentally friendly and sustainable way of living, numerous steps must be taken in order to lighten humanity's impact on the earth. There are many actions that society has already taken towards looking at their environmental footprint and how to reduce it. Programs that promote recycling, reuse, and reduction of materials are already very popular and well known. The next step in this path is to analyze how we can improve upon these processes in order to better utilize the resources that many deem to be "unrecyclable".

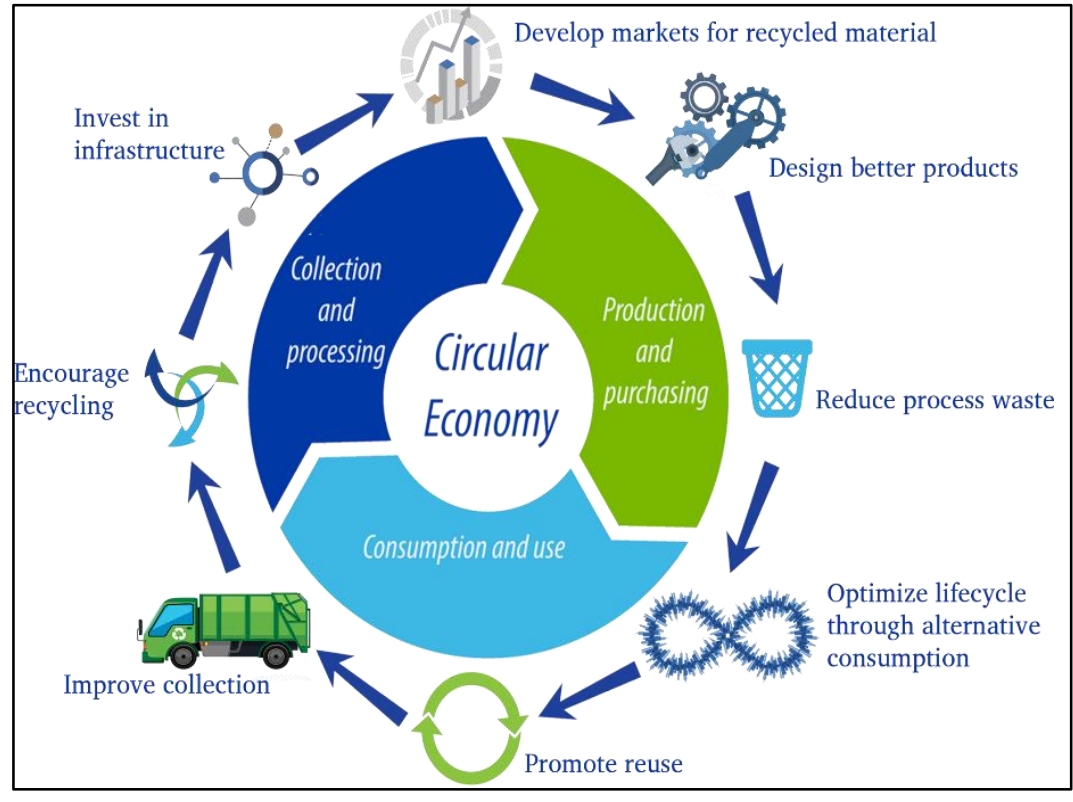

Figure 1: Circular Economy as depicted by the Recycling
The Recycling Council of Ontario depicts an excellent image of key components and actions of what a circular economy would require. As seen in Figure 1, infrastructure is a key component of being able to handle the waste that can be successfully collected and diverted away from more

traditional solid waste collection facilities such as landfills. Ontario has begun moving in the proper direction and different municipalities have already seen the implementation of a form of "green bin" collection program which looks to collect food waste which in the past has been disposed of and not transformed into a value-added product. Another great component of this diagram is the development of markets for these recycled/transformed materials. Not only is 
society reducing the volume of waste going towards other waste facilities, value is also being found in these materials and being reused in ways that were once unimaginable.

A great example of this conversion of waste streams to useful products already exists and has existed for some time even though the public may not be fully aware of its implementation. The public and private sectors currently create value from what might be considered by many to be a "valueless" material. Municipal wastewater and food waste streams being converted to different value-added products is a hot topic that has been thoroughly looked into as a means of providing a new product with greater value than that if it were to be considered as a waste to be disposed of. Methane; better known as biomethane from an environmental standpoint, is taking use of this process. Previously disposed of municipal solid waste and wastewater, through engineered processes, can be transformed to biomethane. One great use for biomethane is its ability to be utilized to generate electricity and further reduce the need for other non renewable sources of energy to be relied upon at their current rate. The impact on the earths carbon footprint is significantly less in this instance. The methane when burned is emitted as carbon dioxide, which has less of an impact on global warming than if methane were to be emitted through gases escaping a landfill. This transformation of waste into biomethane removes waste from landfills and finds a greater use for them. One great thing that research has brought about is the realization that this waste is not just limited to the production of methane as will be discussed in this paper.

In order for a circular economy to succeed, all waste streams must be looked at from different perspectives and continue to be innovated. Food waste and other waste streams are now being looked into to produce other value-added products aside from just methane, one of those products being volatile fatty acids. The goal of the circular economy is ideally, to produce no waste. While we as a society may not currently be at a point of finding value in one hundred percent of 
our waste, being able to find value in different forms is a great way to diversify what we can do with this waste. Continuous advances in processes and finding new uses for materials will help to drive society towards a near perfect circular economy.

\subsection{What are VFAs and how are they produced}

Volatile fatty acids; also known as short chain fatty acids, are fatty acid chains that contain less than six carbon atoms (Brody, 1998). There are a variety of volatile fatty acids that exist and can be produced from many different waste streams. Three of the most common and widely produced VFAs include Acetic Acid $\left(\mathrm{CH}_{3} \mathrm{COOH}\right)$, Propionic Acid $\left(\mathrm{CH}_{3} \mathrm{CH}_{2} \mathrm{COOH}\right)$, and Butyric Acid $\left(\mathrm{CH}_{3} \mathrm{CH}_{2} \mathrm{CH}_{2} \mathrm{COOH}\right)$. In the context of this paper, the VFAs that will be looked at will be primarily produced from different wastewater and food waste streams from various municipal, commercial and institutional industries. However, the volatile fatty acids that we wish to utilize are not easily removed from these streams and thus must be extracted from intermediate steps of anaerobic digestion. In the past, anaerobic digestion was primarily a method of producing methane from these waste streams and volatile fatty acids were often seen as a bi-product of this process. However, there are ways of altering the anaerobic digestion conditions to instead promote the formation of VFAs over methane (Atasoy, Owusu-Agyeman, Plaza, \& Cetecioglu, 2018). This paper will look at a multitude of ways in which reactor conditions have been altered and tested to promote volatile fatty acid production and what optimal conditions appear to be being used by many of the research papers that have been reviewed.

During anaerobic digestion, volatile fatty acids are not always the end-product and as such, they often are converted to methane. The papers that have been reviewed see VFA production as the primary end-product. The goal here is to analyze the different conditions which have been 
tested to look for optimal parameters that show a thriving environment for VFA growth through increases in their concentrations or conversion rates.

Currently in anaerobic digestion, there are four main stages of processing the received waste streams to methane. These stages are Hydrolysis, Acidogenesis, Acetogenesis, and Methanogenesis (Clifford, 2018). The first stage; Hydrolysis (which also includes fermentation),

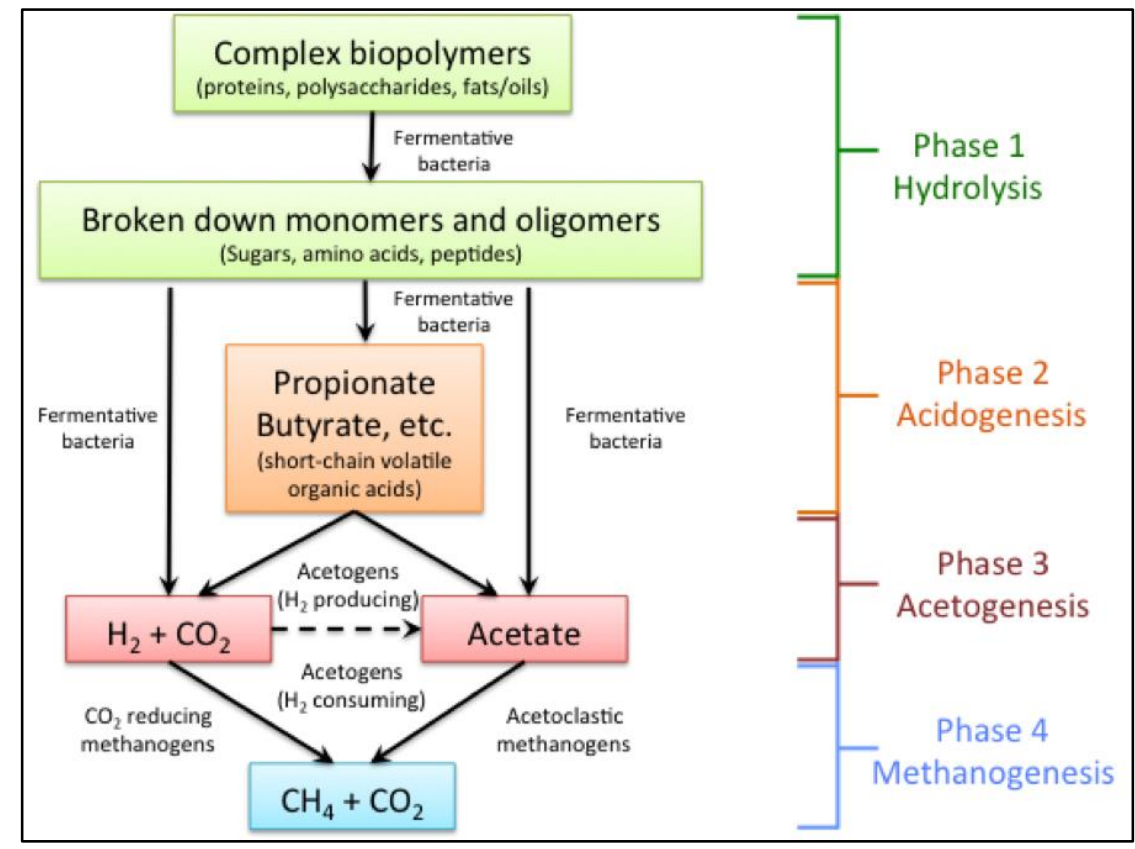

Figure 2: Four stages of biogas production (Clifford, 2018). sees the breakdown of carbohydrates, fats and proteins into sugars (glucose), fatty acids, and amino acids. The next stage; Acidogenesis, sees these products converted into some of the VFAs of interest such as propionic acid and butyric acid (Clifford, 2018). Equation (1)

demonstrates this reaction showing the conversion of sugar (glucose) to one of the desired VFAs; propionic acid (Clifford, 2018).

$$
\mathrm{C}_{6} \mathrm{H}_{12} \mathrm{O}_{6}+2 \mathrm{H}_{2} \rightarrow 2 \mathrm{CH}_{3} \mathrm{CH}_{2} \mathrm{COOH}+2 \mathrm{H}_{2} \mathrm{O} \quad \text { Equation (1) }
$$

The next stage of the anaerobic digestion process is Acetogenesis. During this stage, some of the fatty acids produced during Acidogenesis and remaining glucose are converted to acetic acid through a variety of different reactions. An example of this can be seen in Equation (2) where a reaction between glucose and water react to produce acetic acid (Clifford, 2018). 


$$
\mathrm{C}_{6} \mathrm{H}_{12} \mathrm{O}_{6}+2 \mathrm{H}_{2} \mathrm{O} \rightarrow 2 \mathrm{CH}_{3} \mathrm{COOH}+2 \mathrm{CO}_{2}+4 \mathrm{H}_{2} \quad \text { Equation (2) }
$$

The volatile fatty acids of interest have been produced but the last stage in anaerobic digestion would see them be converted to methane during Methanogenesis. Because the desired end product has been produced, a stop to the anaerobic digestion process (specifically methanogenesis) would need to occur in order to prevent the conversion of the VFAs. Here lies the line where VFA's would either need to be extracted or the Methanogenesis stage inhibited through whatever means required. There have been suggested means which as to inhibit the methanogenesis stage, one of them being the shortening of retention/reaction time which would prevent methane from being formed as it is a process which takes time (Atasoy, Owusu-Agyeman, Plaza, \& Cetecioglu, 2018). Adjusting the $\mathrm{pH}$ within certain ranges is also a feasible idea as methanogenesis would be inhibited and VFA's would be allowed to continue forming (Atasoy, Owusu-Agyeman, Plaza, \& Cetecioglu, 2018). As will be discussed throughout this paper, there are a variety of conditions that the anaerobic digestion process can go through in order to promote the yields and concentrations of VFAs. This will encourage VFAs to be looked at as primary products of altered anaerobic digestion processes rather than just a biproduct of them in the formation of methane or biogas.

\subsection{Substrate (Feed)}

The type of waste stream that is chosen in the production of volatile fatty acids has a direct effect on potential yields. All waste streams are different to a degree in terms of their physical characteristics and their chemical compositions. Additionally, the ease of production of VFAs from these different waste streams can vary with respect to each waste type. Common types of waste streams seen in this paper include food waste and different forms of wastewater (dairy, winery, municipal sludge etc.). The different waste streams have the potential to yield varying VFA yields or types of VFAs. As seen in studies such as Feng et al. (2013), the composition of the 
substrate (Waste activated sludge in this instance) has the possibility of inhibiting the production of specific VFAs (propionic acid in this scenario) due to the various properties of the waste (in this case high protein content and a low Carbon to Nitrogen ratio) (Feng, Chen, \& Zheng, 2009). Therefore, when selecting a specific substrate to be converted to VFAs, careful planning and research must be done into understanding the properties of a waste stream and what methods can be used to enhance their production and dissuade their inhibition.

Not all waste streams are as sought after due to properties which might make the waste difficult to convert to the desired VFAs. However, the practice of co-digestion is of interest for wastes with properties that do not digest well alone due to factors such as a lack of nutrients. However once combined with another waste stream, the interaction of the two wastes allows for a more desired conversion into VFAs. This can be seen in studies such as Zhu et al. (2008) where the digestion of food waste alone produced lesser concentrations of VFAs but when co-digested with other wastes, much higher VFA yields were seen (Zhu, et al., 2008). Therefore, the investigation of different possible substrate combinations has the potential to utilize waste streams that may not appear as favorable at first glance but can end up providing desired VFAs.

\subsection{Inoculum (Microorganisms)}

While the selection and understanding of the substrates properties is a vital parameter in anaerobic digestion, the selection of the proper inoculum to compliment the substrate is equally as important. The inoculum contains the desired microorganisms which will be degrading the waste into the desired products (VFAs in this scenario). Therefore, consideration of specific microorganisms to deal with wastes can lead to optimal conversion rates and breakdown of the waste. There are several important bacteria that are apart of the inoculum, these include "hydrolytic bacteria, acidogenic bacteria, acetogens and methanogens" (Zhou, Yan, Wong, \& Zhang, 2018). 
As discussed in section 1.2, the last step of traditional anaerobic digestion; methanogenesis, sees the VFAs that have been produced be converted to other products, mainly methane. Therefore, the methanogens that are present in the last stage of anaerobic digestion would need to be avoided altogether or at least inhibited if VFAs are planning on being produced as the primary product.

As discussed in section 1.2 and throughout this paper, there are several methods that can be used to go about reducing the likelihood of methane production by altering the conditions during the anaerobic digestion process. However, there are also steps that can be taken to alter the inoculum and reduce its methane producing properties. One such example is seen in Yan et al. (2014) where inoculum was heat treated in order to deactivate the methanogens that would be present later on. This process kills the hydrogenothrophic methanogens leaving the homoacetogenesis process to produce acetate from Hydrogen and Carbon Dioxide that is present (Yan, Selvam, Xu, \& Wong, 2014). This is a huge benefit as not only are you preventing methanogens from forming, but you are also producing one of the desired VFAs; acetate.

Therefore, it can be seen that a key contributor in the production of VFAs; the inoculum, serves a great purpose in ensuring that there is a successful conversion process. The key microorganisms needed during the hydrolysis, acidogenesis, and acetogenesis stages are provided by the inoculum. If steps are taken to treat the inoculum, then they also have the capabilities to reduce methane production which in turn boosts the possibility of VFAs being produced. 


\section{Operating Conditions}

\subsection{Types of Bioreactors / Digesters}

The configuration and type of a bioreactor/digester play a key role on their success and efficiency. The type or configuration can often be dictated by the type of waste that is to be processed at the specific digester. With each configuration comes varying processes and conditions that are to be utilized if a process is to be made as efficient as possible. Additionally, there exist many advantages and disadvantages to each technology and therefore they all warrant different scenarios to be optimal.

Two main categories of reactors exist that are commonly used in the production of Volatile Fatty Acids are suspended growth and attached growth reactors (Eddy \& Metcalf, 1979). In suspended growth bioreactors, microbes that are present in the inoculum are the driving force to break down the waste streams that are fed into the reactors. These microbes are suspended in the mixture and are kept in motion dependant on the type of reactor. Common examples of suspended growth reactors include batch reactors, continuous stirred tank reactors (CSTR) and plug flow reactors. Attached growth reactors operate in a different manner due to how the microorganisms interact with the waste stream. In these reactors, a medium is used to allow the microbes a surface to grow on. Common mediums include different shaped plastics, membranes or other porous material (sand) that suspended carriers can grow on. This allows a bio film to form on the mediums which then interact with the waste stream to break down the mixture. These mediums can be kept in motion in the case of fluidized bed reactors or remain stationary and have the waste pass through them like in membrane bioreactors. 


\subsection{Effect of $\mathrm{pH}$}

As mentioned in the introduction, the conversion of different waste streams to VFAs are generally done through anaerobic digestion generally in the phases of acidogenesis (formation of propionic acid and butyric acid) and acetogenesis (formation of acetic acid). The subsequent stage in anaerobic digestion would be methanogenesis which would see the conversion of the desired VFAs into methane. Therefore, to prevent and or inhibit the methanogenesis process, suboptimal conditions for methanogenesis would be recommended where acidogenesis and acetogenesis could thrive. With regards to $\mathrm{pH}$, there are generally accepted optimal ranges for methanogenesis to occur at. Methanogenesis can operate in a $\mathrm{pH}$ ranging from about 5.5 to 8.5 with an optimal $\mathrm{pH}$ range from 6.5 to 8 (Nielsen \& Ahring, 2006). This is a somewhat narrow range of $\mathrm{pH}$ values for methane to be produced within and therefore in order to inhibit methanogenesis and still allow for VFAs to be formed, a $\mathrm{pH}$ range outside of this must be found that is suitable for acidogenesis and acetogenesis.

Below in Table 1, a compilation of several journal articles have been reviewed regarding $\mathrm{pH}$ 's effect on VFA production. These studies have $\mathrm{pH}$ as one of the parameters that have been varied in order to identify the effect of changing the $\mathrm{pH}$ with regards to VFA productions / concentrations. Of the articles selected for comparison, ones with several $\mathrm{pH}$ ranges were preferred to allow for conclusions to be drawn from within each study. Reference 3, 4, 6, and 7 from Table 1 immediately stand out from the rest of the sources due to their $\mathrm{pH}$ being more alkaline compared to papers 1,2 , and 5 . The reason they stand out is in part due to them being outside the optimal range for methanogenesis (mentioned above), that being in a $\mathrm{pH}$ range of 6.5 to 8 . The significance of this is that it shows that more alkaline pHs ranging from around 9 to 10 show the potential for greater VFA production capabilities. 


\begin{tabular}{|c|c|c|c|c|c|}
\hline Ref. \# & Waste & pH Level & VFA Production & Reactor Configuration & Reference \\
\hline \multirow{3}{*}{ [1] } & \multirow{3}{*}{ Granular Sludge } & 4.5 & $0.66 \pm 0.02 \mathrm{gCOD} / \mathrm{gCOD}$ & \multirow{3}{*}{$\begin{array}{c}\text { Lab scale anaerobic sequencing } \\
\text { batch reactor (ASBR) }\end{array}$} & \multirow{3}{*}{ Tamis et al. (2015) } \\
\hline & & 5 & $0.60 \pm 0.03 \mathrm{gCOD} / \mathrm{gCOD}$ & & \\
\hline & & 5.5 & $0.59 \pm 0.03 \mathrm{gCOD} / \mathrm{gCOD}$ & & \\
\hline \multirow{3}{*}[2]{} & \multirow{3}{*}{ Food Waste } & 4 & $124.30 \mathrm{mg} / \mathrm{gVSS}$ & \multirow{3}{*}{$\begin{array}{c}\text { Batch Reactors (Wide mouth } \\
\text { bottles) }\end{array}$} & \multirow{3}{*}{ Wang et al. (2014) } \\
\hline & & 5 & $650.76 \mathrm{mg} / \mathrm{gVSS}$ & & \\
\hline & & 6 & $918.23 \mathrm{mg} / \mathrm{gVSS}$ & & \\
\hline \multirow{4}{*}{ [3] } & \multirow{4}{*}{$\begin{array}{l}\text { Primary and Waste } \\
\text { Activated Sludge }\end{array}$} & 7 & $38.19 \pm 3.67 \mathrm{mg} C O D / g$ VSS & \multirow{4}{*}{$\begin{array}{l}\text { Semi-continuous commercial } \\
\text { fermenter }\end{array}$} & \multirow{4}{*}{ Chen et al. (2017) } \\
\hline & & 7.9 & $119.57 \pm 10.36 \mathrm{mg}$ COD $/ \mathrm{g}$ VSS & & \\
\hline & & 8.9 & $423.22 \pm 25.49 \mathrm{mg}$ COD$/ \mathrm{g}$ VSS & & \\
\hline & & 9.9 & $276.40 \pm 9.15 \mathrm{mg} C O D / g$ VSS & & \\
\hline \multirow{5}{*}{ [4] } & \multirow{5}{*}{$\begin{array}{l}\text { Spent Mushroom } \\
\text { Compost }\end{array}$} & 4 & 950 mg/L (estimate) & \multirow{5}{*}{ Batch Reactors } & \multirow{5}{*}{ Fang et al. (2017) } \\
\hline & & 6 & 1950 mg/L (estimate) & & \\
\hline & & 8 & $2500 \mathrm{mg} / \mathrm{L}$ (estimate) & & \\
\hline & & 10 & $3479.59 \mathrm{mg} / \mathrm{L}$ & & \\
\hline & & 12 & 1875 mg/L (estimate) & & \\
\hline \multirow{3}{*}[5]{} & \multirow{3}{*}{$\begin{array}{c}\text { Simulated Food } \\
\text { Waste }\end{array}$} & 5 & $17.08 \mathrm{~g} / \mathrm{L}$ & \multirow{3}{*}{ Batch Reactors } & \multirow{3}{*}{ Jiang et al. (2013) } \\
\hline & & 6 & $39.46 \mathrm{~g} / \mathrm{L}$ & & \\
\hline & & 7 & $37.09 \mathrm{~g} / \mathrm{L}$ & & \\
\hline \multirow{6}{*}[6]{} & & 3 & $60 \mathrm{mg}$ COD/g VS * & \multirow{6}{*}{ Batch Reactors } & \multirow{6}{*}{ Liu et al. (2012) } \\
\hline & & 5 & $180 \mathrm{mg}$ COD/g VS * & & \\
\hline & Proteinaceous & 7 & $535 \mathrm{mg}$ COD/g VS * & & \\
\hline & Sewage Sludge & 9 & $620 \mathrm{mg}$ COD/g VS * & & \\
\hline & & 11 & 575 mg COD/g VS * & & \\
\hline & & 12 & $220 \mathrm{mg}$ COD/g VS * & & \\
\hline \multirow{6}{*}{ [7] } & \multirow{2}{*}{ Sewage Sludge } & 5.5 & 0.20 gVFA/gCOD & \multirow{6}{*}{ Batch Reactor (Pyrex Bottles) } & \multirow{6}{*}{$\begin{array}{c}\text { Esteban-Gutierrez et al. } \\
\text { (2018) }\end{array}$} \\
\hline & & 10 & 0.40 gVFA/gCOD & & \\
\hline & Whoru Wractowator & 5.5 & 0.35 gVFA/gCOD & & \\
\hline & viliteiy vadstewate! & 10 & 0.40 gVFA/gCOD & & \\
\hline & \multirow{2}{*}{$\begin{array}{l}\text { Meat and Bone } \\
\text { Meal }\end{array}$} & 5.5 & 0.34 gVFA/gCOD & & \\
\hline & & 10 & 0.49 gVFA/gCOD & & \\
\hline
\end{tabular}

Table 1: Compilation of studies effects of pH on VFA production. Note: Shaded values represent highest VFA concentrations for each study, VFA productions with an asterisk " * "are approximations taken from figures where exact values are not specified. 
To follow up with the pattern of optimal $\mathrm{pH}$ ranges shown in Table 1, Figure 3 taken from Jankowska et al. clearly paints a picture of optimal conditions for volatile fatty acid production. Here you can see for a retention time of five days, there are two peaks and a valley. This valley appears to be near the optimal range for the methanogenesis ( $\mathrm{pH}$ of 6.5 to 8) as previously discussed. This signifies lower VFA productions in this region when compared to the two valleys

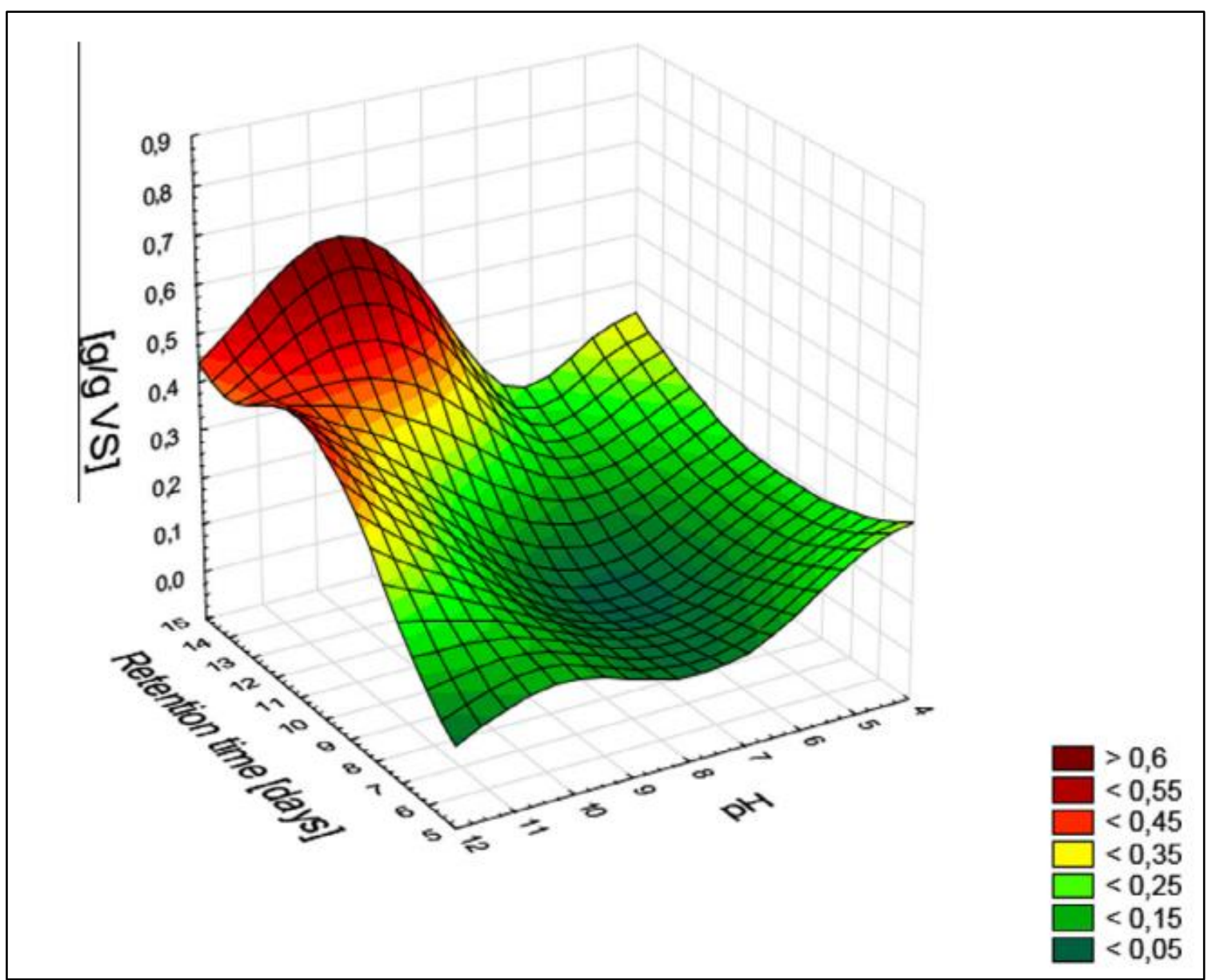

Figure 3: Total VFA production changes due to changes in $\mathrm{pH}$ and retention time taken from Jankowsca et al.(2015) (Jankowska, Chwialkowska, Stodolny, \& Oleskowicz-Popiel, 2015).

next to it. This clearly shows that the $\mathrm{pH}$ range for the valley is less productive at producing VFAs and therefore not optimal. A significant conclusion can be drawn due to the fact that as the retention time increases to fifteen days, total VFA production continues to increase, especially within the $\mathrm{pH}$ range of around 9 to 11 . There are two things that can be taken away from the high VFA 
production peak at fifteen days of retention time. Firstly, it could suggest that the alkaline $\mathrm{pH}$ may have prevented, or at least significantly decreased the methanogenesis process. This could explain the high VFA production rates / concentrations because rather than a large portion of VFAs being converted to methane, they were instead allowed to continue forming thus resulting in their high concentrations. Secondly, the large peak for the VFA concentrations of the alkaline $\mathrm{pH}$ region far exceeds that of the acidic region. This could suggest that an alkaline setting is a more optimal $\mathrm{pH}$ condition for VFA, specifically ranging from around a $\mathrm{pH}$ of 9 to 11.

With reference to Table 1 and Figure 3, a set of conditions for the optimal pH for VFA production can be visualized. In Table 1, references 4 and 6 have a good spread of tested $\mathrm{pH}$ values ranging from 3 to 12. In both of these studies, the optimal $\mathrm{pH}$ conditions ranged from 9 to 10 . This shows that within each study, an alkaline condition out performs the acidic condition. Looking back at figure 3, this also lines up with the results produced at the fifteen-day retention time results. Again, the alkaline $\mathrm{pH}$ out performs the acidic $\mathrm{pH}$ in terms of VFA concentrations. This is further demonstrated in reference 7 from Table 1. Using three different food waste streams, under the same conditions, the alkaline $\mathrm{pH}$ of 10 outperforms the acidic $\mathrm{pH}$ of 5.5 again demonstrating the alkaline $\mathrm{pH}$ to be the more optimal condition in terms of VFA production.

What is important to take away from this analysis is that a key factor in ensuring optimal VFA production is to avoid or inhibit the methanogenesis process. By avoiding the optimal $\mathrm{pH}$ region for methanogenesis, the ability for VFAs to form and not be converted to methane is promoted. It can be seen that both acidic and alkaline $\mathrm{pH}$ conditions allow for VFA production. However, alkaline conditions tend to produce higher VFA concentrations as seen in several examples in Table 1 and clearly demonstrated in Figure 3. It can also be said that the specific VFA produced varies dependant on the $\mathrm{pH}$ conditions. 


\subsection{Effect of Temperature}

Temperature in a reactor can play a large part in affecting the breakdown on waste and the stages of anaerobic digestion. There are generally two temperature ranges that are associated with the anaerobic digestion process; those being thermophilic and mesophilic. Thermophilic temperatures usually range upwards of $50{ }^{\circ} \mathrm{C}$ while mesophilic temperatures range from 30 to $40{ }^{\circ} \mathrm{C}$ (Kim, Gomec, Ahn, \& Speece, 2003). Both temperature ranges also show different production characteristics in terms of the type of VFA produced as well as the effects on the anaerobic digestion process, specifically hydrolysis. Depending on what type of volatile fatty acid is desired, a range of different temperatures allows for a different VFA to be more dominantly produced. Results from Kim et al. (2003) showed that operating under mesophilic and thermophilic conditions at a variety of $\mathrm{pH}$ levels would produce different concentrations of VFAs (specifically acetate, propionate, butyrate and lactate). Additionally, Kim et al. (2003) concluded that hydrolysis and the growth of microorganisms is affected by temperature, therefore temperature not only affected yields but also the processes leading up to the yields (Kim, Gomec, Ahn, \& Speece, 2003). Therefore, in order to make a solid argument for one temperature range over another, a more specific look into each VFAs preferred conditions might be required.

\subsubsection{Mesophilic}

Kim et al. (2002); Reference 8, Table 2, studied the effects of multiple reactor configurations under the effects of mesophilic $\left(35^{\circ} \mathrm{C}\right)$ and thermophilic $\left(55^{\circ} \mathrm{C}\right)$ conditions. The four reactor configurations tested are daily batch-fed single stage CSTR (B), continuously fed single stage CSTR (C), daily batch-fed two-phase CSTR (TP), daily batch-fed non-mixed reactor (NMR) (Kim, Ahn, \& Speece, 2002). The C and B reactors under thermophilic conditions heavily outperformed the mesophilic one while the NMR performed on par for both temperatures. Of the 
four reactors tested, only the TP reactor outperformed under mesophilic conditions. However, the concentration of VFAs for this reactor configuration under mesophilic conditions produced concentrations of VFAs more than double that of its thermophilic counterpart (seen in Table 2, Reference 8). Additionally, the portion of these VFAs that were propionate were significantly higher in this circumstance. Therefore, it is shown that under certain conditions, mesophilic temperatures have the ability to produce higher concentrations of VFAs (in the case of Kim et al (2002) it was the reactor configuration). Additionally, it is shown that there can be higher yields of propionate found in mesophilic temperatures which may be of interest if it is the primary VFA that is looking to be produced.

With reference to Table 2 below, reference 6; Hao et al. (2015) shows the outperformance in terms of VFA production by the thermophilic temperature range. However, a closer look into this study does reveal that a larger percentage of propionic acid and butyric acid were formed in the mesophilic conditions. Reference 5 from Table 2; Jiang et al. (2013) found a temperature of $45^{\circ} \mathrm{C}$ to have the highest VFA production rate. Under these mesophilic conditions, acetate and propionate were the most produced VFAs. Additionally, their production severely diminished when thermophilic conditions were tested meaning they might be more prevalent in mesophilic conditions. These results coincide with Kim et al. (2002) which demonstrated that high concentrations of propionate were formed under mesophilic temperatures (Table 2, Reference 8). This could point towards propionate being a VFA that is generally produced in higher concentrations under mesophilic conditions.

\subsubsection{Thermophilic}

An important stage of anaerobic digestion is hydrolysis. As discussed in section 1.2, hydrolysis sees the initial breakdown of the waste into components that will then be converted into 
VFAs. The proceeding stage; acidification, sees the first VFAs formed. Therefore, if these stages can be enhanced, then the total available waste components to be converted to VFAs can be maximized. Research conducted by He et al. (2012) demonstrates the role that temperature plays in the hydrolysis and acidification stages of anaerobic digestion. Temperatures tested were a combination of mesophilic and thermophilic, those being 35,55 , and $70{ }^{\circ} \mathrm{C}$. The best performing temperature in terms of VFA production for this set was $35^{\circ} \mathrm{C}$ with concentrations around 16,775 $\mathrm{mg} / \mathrm{L}$ at its maximum (seen in Table 2, Reference 7). There are several important takeaways from their findings. Firstly, the growing range of the yeast (between $0^{\circ} \mathrm{C}$ and $47^{\circ} \mathrm{C}$ ) was only met for the $35^{\circ} \mathrm{C}$ temperature, therefore, there was a large amount of ethanol produced at $35^{\circ} \mathrm{C}$ that the other two temperatures did not see (much smaller ethanol yields in comparison) (He, et al., 2012). Secondly, as discussed in the introduction of this section, the range in temperatures has an effect on which VFA is produced. He et al. (2012) reported that each temperature tested had distinct VFAs that were produced in majority. Acetic acid was produced in the highest concentrations at $70{ }^{\circ} \mathrm{C}$ at $5664.28 \mathrm{mg} / \mathrm{L}$ which was 3.26 and 0.89 times as much seen at $35^{\circ} \mathrm{C}$ and $55^{\circ} \mathrm{C}$ respectively (He, et al., 2012). Isobutyric and butyric acid were produced in highest concentrations at $55^{\circ} \mathrm{C}$ with $70^{\circ} \mathrm{C}$ following it as the second highest producer. Overall, at both Thermophilic temperatures, specific VFA concentrations were higher than those seen at $35^{\circ} \mathrm{C}$. It can be seen that there are benefits of operating at both Mesophilic and Thermophilic temperatures depending on what goals are desired. If specific VFAs such as acetate and butyrate are desired, then the consideration of Thermophilic temperatures may be more useful as the distinct conditions have been tested to produce certain VFAs.

Similar results as discussed in He et al. (2012) can be seen in the results of Jiang et al. (2013) and Zhang et al. (2009) where thermophilic temperatures yield higher concentrations of 
certain VFAs when compared to their mesophilic counterparts (discussed below). Reference 5 from Table 2; Jiang et al. (2013) found that butyric acid was more readily produced at a thermophilic condition comprising $81.12 \%$ of VFAs when tested at $55^{\circ} \mathrm{C}$. This was severely less compared to the percent of butyrate produced at $35^{\circ} \mathrm{C}$ and $45^{\circ} \mathrm{C}$ which was $21.89 \%$ and $25.57 \%$ respectively. This large shift away from butyrate at mesophilic conditions might suggest that butyrate production is enhanced in thermophilic conditions.

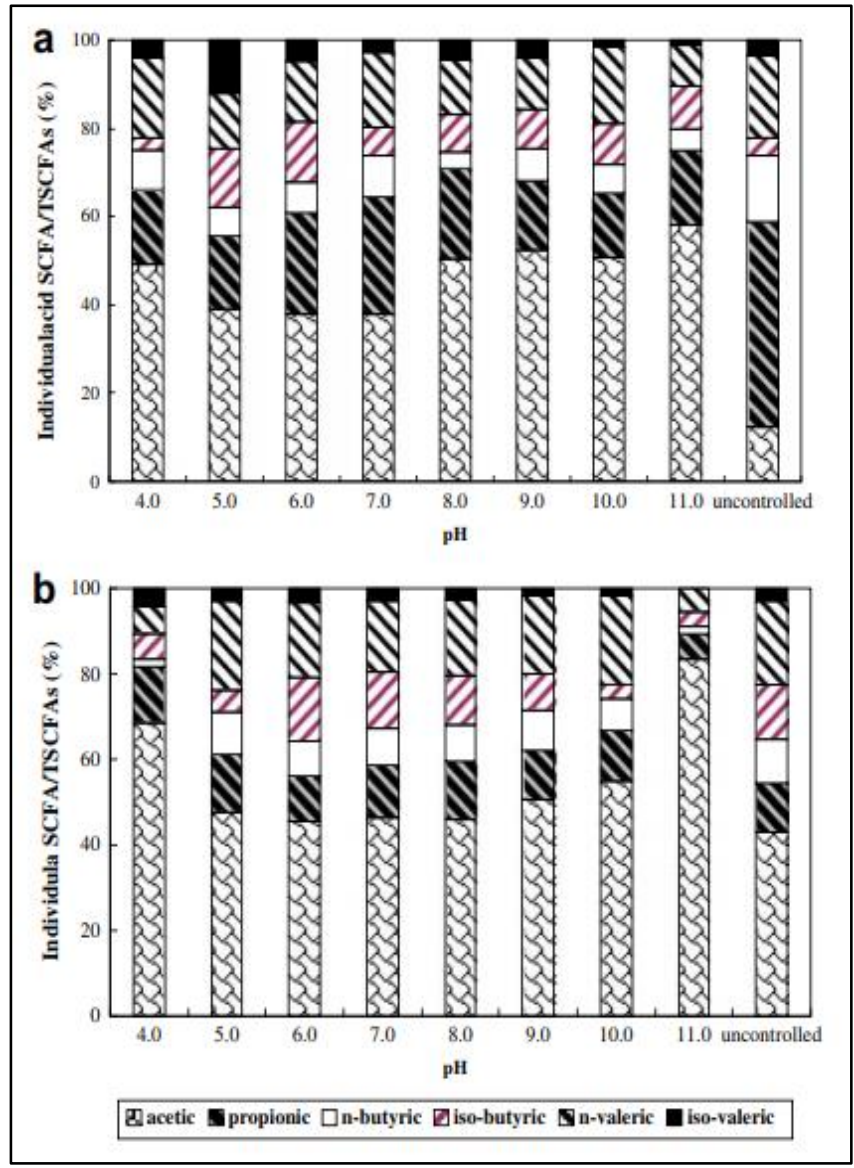

Figure 4: Chart $a$ - mesophilic conditions, Chart $b$ -thermophilic conditions, taken from Zhang et al. (2009).
Not included in Table 2 but useful for discussion, is Figure 4 taken from Zhang et al. (2009). At two different pHs of 4 and 11, it is shown that production of acetate is significantly higher under thermophilic conditions. Mesophilic saw the production of around $50 \%$ and $60 \%$ acetate for $\mathrm{pH} 4$ and 11 respectively while thermophilic conditions saw production around $70 \%$ and $80 \%$ for $\mathrm{pH} 4$ and 11 respectively. It can be seen that there is around a $20 \%$ increase in acetate production when operating under thermophilic conditions at these $\mathrm{pH}$ levels. 


\begin{tabular}{|c|c|c|c|c|c|}
\hline $\begin{array}{c}\text { Ref. } \\
\# \\
\end{array}$ & Waste & Temperature & VFA Production & $\begin{array}{c}\text { Reactor } \\
\text { Configuration } \\
\end{array}$ & Reference \\
\hline \multirow{3}{*}{ [1] } & \multirow{3}{*}{$\begin{array}{l}\text { Waste } \\
\text { Activated } \\
\text { Sludge }\end{array}$} & $4{ }^{\circ} \mathrm{C}$ & 109 gVFA-COD / gVSS & \multirow{3}{*}{$\begin{array}{l}\text { Bench scale batch } \\
\text { reactor (with } \\
\text { mixing) }\end{array}$} & \multirow{3}{*}{$\begin{array}{l}\text { Yuan et al. } \\
\text { (2011) }\end{array}$} \\
\hline & & $14^{\circ} \mathrm{C}$ & 296 gVFA-COD / gVSS & & \\
\hline & & $24.6^{\circ} \mathrm{C}$ & 355 gVFA-COD / gVSS & & \\
\hline \multirow{3}{*}[2]{} & \multirow{3}{*}{$\begin{array}{l}\text { Primary } \\
\text { Sludge }\end{array}$} & $22^{\circ} \mathrm{C}$ & 0.041 mgVFA / mgVSS day & \multirow{3}{*}{$\begin{array}{l}\text { Bench scale mixed } \\
\text { reactor }\end{array}$} & \multirow{3}{*}{$\begin{array}{c}\text { Banerjee et } \\
\text { al. (1998) }\end{array}$} \\
\hline & & $30{ }^{\circ} \mathrm{C}$ & 0.048 mgVFA / mgVSS day & & \\
\hline & & $35^{\circ} \mathrm{C}$ & 0.033 mgVFA / mgVSS day & & \\
\hline \multirow{6}{*}{ [3] } & \multirow{6}{*}{$\begin{array}{l}\text { Primary } \\
\text { Sludge }\end{array}$} & $8^{\circ} \mathrm{C}$ & $290 \mathrm{mg} / \mathrm{L}^{*}$ & \multirow{6}{*}{$\begin{array}{l}\text { Continuous flow } \\
\text { mixed anaerobic } \\
\text { reactor }\end{array}$} & \multirow{6}{*}{$\begin{array}{l}\text { Maharaj et } \\
\text { al. (2001) }\end{array}$} \\
\hline & & $16^{\circ} \mathrm{C}$ & $460 \mathrm{mg} / \mathrm{L}^{*}$ & & \\
\hline & & $22^{\circ} \mathrm{C}$ & $545 \mathrm{mg} / \mathrm{L}$ * & & \\
\hline & & $25^{\circ} \mathrm{C}$ & $780 \mathrm{mg} / \mathrm{L}^{*}$ & & \\
\hline & & $30^{\circ} \mathrm{C}$ & $625 \mathrm{mg} / \mathrm{L}$ * & & \\
\hline & & $35^{\circ} \mathrm{C}$ & $490 \mathrm{mg} / \mathrm{L} *$ & & \\
\hline \multirow{6}{*}[4]{} & \multirow{2}{*}{$\begin{array}{l}\text { Sewage } \\
\text { Sludge }\end{array}$} & $35^{\circ} \mathrm{C}$ & 0.32 gVFA/gCOD & \multirow{6}{*}{$\begin{array}{l}\text { Batch Reactor } \\
\text { (Pyrex Bottles) }\end{array}$} & \multirow{6}{*}{$\begin{array}{l}\text { Esteban- } \\
\text { Gutierrez } \\
\text { et al. } \\
(2018)\end{array}$} \\
\hline & & $55^{\circ} \mathrm{C}$ & 0.4 gVFA/gCOD & & \\
\hline & \multirow{2}{*}{$\begin{array}{c}\text { Winery } \\
\text { Wastewater }\end{array}$} & $35^{\circ} \mathrm{C}$ & 0.28 gVFA/gCOD & & \\
\hline & & $55^{\circ} \mathrm{C}$ & 0.4 gVFA/gCOD & & \\
\hline & \multirow{2}{*}{$\begin{array}{l}\text { Meat and } \\
\text { Bone Meal }\end{array}$} & $35^{\circ} \mathrm{C}$ & 0.39 gVFA/gCOD & & \\
\hline & & $55^{\circ} \mathrm{C}$ & 0.49 gVFA/gCOD & & \\
\hline \multirow{3}{*}[5]{} & \multirow{3}{*}{$\begin{array}{l}\text { Simulated } \\
\text { food waste }\end{array}$} & $35^{\circ} \mathrm{C}$ & $41.34 \mathrm{~g} / \mathrm{L}$ & \multirow{3}{*}{ Batch reactor } & \multirow{3}{*}{$\begin{array}{l}\text { Jiang et al. } \\
\text { (2013) }\end{array}$} \\
\hline & & $45^{\circ} \mathrm{C}$ & $47.89 \mathrm{~g} / \mathrm{L}$ & & \\
\hline & & $55^{\circ} \mathrm{C}$ & $14.90 \mathrm{~g} / \mathrm{L}$ & & \\
\hline \multirow[b]{2}{*}[6]{} & \multirow[b]{2}{*}{$\begin{array}{c}\text { Sludge } \\
\text { (wastewater) }\end{array}$} & $55^{\circ} \mathrm{C}$ & $5627.3 \pm 354.6 \mathrm{mg} \mathrm{COD} / \mathrm{L}$ & \multirow{2}{*}{$\begin{array}{l}\text { Glass bottles } \\
\text { (acting as } \\
\text { fermentation } \\
\text { reactor) }\end{array}$} & \multirow[b]{2}{*}{$\begin{array}{l}\text { Hao et al. } \\
(2015)\end{array}$} \\
\hline & & $35^{\circ} \mathrm{C}$ & $574.4 \pm 29.2 \mathrm{mg} \mathrm{COD} / \mathrm{L}$ & & \\
\hline \multirow{3}{*}{ [7] } & \multirow{3}{*}{ Food waste } & $35^{\circ} \mathrm{C}$ & $16,775 \mathrm{mg} / \mathrm{L} *$ & \multirow{3}{*}{$\begin{array}{c}\text { Two-phase } \\
\text { anaerobic digestion }\end{array}$} & \\
\hline & & $55^{\circ} \mathrm{C}$ & $11,400 \mathrm{mg} / \mathrm{L}^{*}$ & & He et al. \\
\hline & & $70^{\circ} \mathrm{C}$ & $13,650 \mathrm{mg} / \mathrm{L}^{*}$ & & \\
\hline & & $35^{\circ} \mathrm{C}$ & 142 COD mg / L & Daily batch-fed & \\
\hline & & $55^{\circ} \mathrm{C}$ & 4307 COD mg / L & single stage CSTR & \\
\hline & & $35^{\circ} \mathrm{C}$ & 129 COD mg / L & Continuously fed & \\
\hline [8] & Rол Fond & $55^{\circ} \mathrm{C}$ & 4133 COD mg / L & single stage CSTR & Kim et al. \\
\hline$[0]$ & Log roun & $35^{\circ} \mathrm{C}$ & 5105 COD mg / L & Daily batch-fed & (2002) \\
\hline & & $55^{\circ} \mathrm{C}$ & 2444 COD mg / L & two-phase CSTR & \\
\hline & & $35^{\circ} \mathrm{C}$ & $161 \mathrm{COD} \mathrm{mg} / \mathrm{L}$ & Daily batch-fed & \\
\hline & & $55^{\circ} \mathrm{C}$ & $162 \mathrm{COD} \mathrm{mg} / \mathrm{L}$ & non-mixed reactor & \\
\hline
\end{tabular}

Table 2: Compilation of studies effects of Temperature on VFA production. Note: Shaded values represent highest VFA concentrations for each study. VFA productions with an asterisk "* " are approximations taken from figures where exact values are not specified. 
Determining an optimal temperature for VFA production is not as easy as selecting the most common optimal temperature because there are a variety of factors to take into consideration simultaneously such as the type of waste, $\mathrm{pH}$, etc. There are questions that should be asked that are outside the scope of this paper that might better give answers to finding an "optimal" temperature. For example, it would be worth analyzing if the additional production of acetic acid under thermophilic conditions (as demonstrated in Zhang et al. (2009)) is worth the extra temperature needed to produce it. The economic feasibility of producing this extra acetate would involve higher operating temperatures which would result in additional costs due to heating. A question such as this could be posed for every different scenario imaginable where the operating temperature would vary based on different parameters already in place.

Overall it is difficult to say what the optimal temperature may be as it is dependant on the waste's characteristics as well as what the desired VFA to be produced is. To properly determine an optimal condition, it might be feasible to first investigate the market value of each individual VFA and possibly cater the temperature and other anaerobic operating conditions to the desired VFA to be produced. Either way, it has been proven that both mesophilic and thermophilic temperatures can be successful at producing VFAs. Both temperature ranges have shown to be superior to the other under different circumstances. As seen in Table 2, there were several thermophilic temperatures with better production rates than their mesophilic counterparts. Some research evidence points towards thermophilic temperatures aiding in the hydrolysis process (Zhang, Chen, \& Zhou, 2009) but at the price of increased operating costs. As such, mesophilic temperatures could be considered as a better potential condition as they have been shown to outperform or perform close to thermophilic conditions while being able to be operated at a lower cost due to less required heating. 


\subsection{Effect of Retention Time / Organic Loading Rate}

Organic loading rate (OLR) and retention time (RT) are vital parameters when it comes to the productivity of VFAs. Organic loading rate can be seen as the rate at which the feed is fed into the reactor while retention time (hydraulic retention time) is the duration that feed remains in the reactor. The two terms can be used somewhat interchangeably but are distinct in their units, organic loading rate generally being a unit of mass per period of time per unit volume while retention time is strictly a unit of time. They do however relate to the principal of how long feed remains in the reactor before it is replaced. An example of this being a high OLR (meaning a lot of mass is being fed through a reactor) would corelate to a low retention time as the feed would not remain in the reactor for extended periods. The importance of these concepts is making sure that a reactor, specifically the microorganisms within a reactor, are given enough time to break down the feed that is being supplied to them. Not enough time (short RT or high OLR) has the possibility of yielding a digestate that is still rich in product that has not been converted to VFAs. On the other hand, too long spent in the reactor (long RT or low OLR) would result in maximum VFA concentrations being produced early in the digestion process, but wasting time residing in reactor when no further increases to VFA concentrations would be seen. Therefore, a balancing act of a feed's optimal time spent in a reactor would be an important parameter to be investigated. Not looking into an optimal OLR or RT could result in loses in efficiencies as reactors would either be wasting time due to over handling the feed or wasting resources by not processing them long enough (not producing maximum/optimal VFAs).

Scenarios such as these are demonstrated in Lim et al. (2008) (values under Table 3,

Reference 5) where maximum VFA concentrations are reached at a hydraulic retention time of around 12 days for the feed being tested. See Figure 5 below from Lim et al. (2008). In this instance, 
the maximum VFA concentration values of around 20.5 to $22.0 \mathrm{~g} / \mathrm{L}$ are found for a higher HRT of 12 days. The 4 and 8-day retention times (4 and 8-day RT figure from Lim et al. 2008 have not been included) produce significantly lower VFA concentrations of $5.0-6.0 \mathrm{~g} / \mathrm{L}$ and $13.0-14.0$ $\mathrm{g} / \mathrm{L}$ respectively. These results demonstrate that the lower HRTs did not allow the feed enough

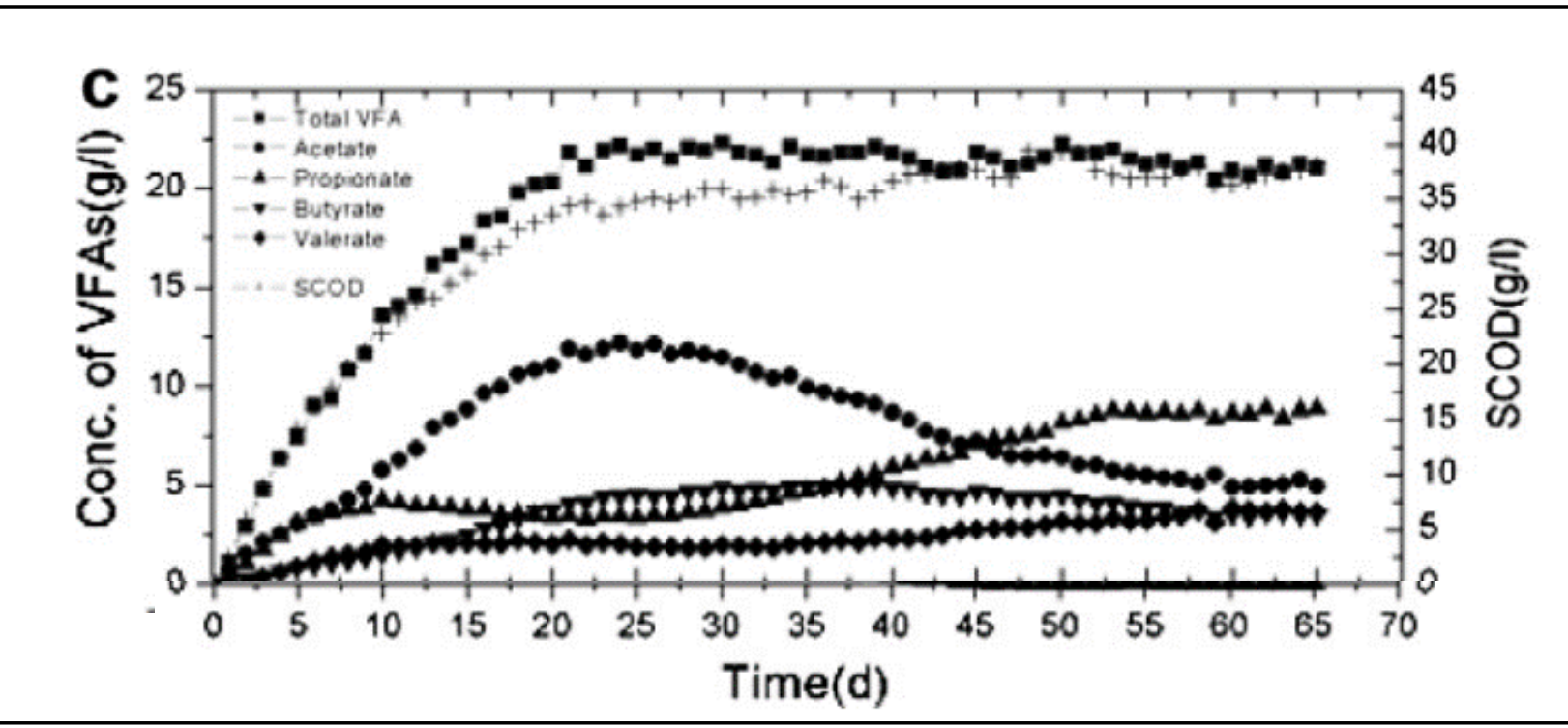

Figure 5: VFA concentrations for a 12-day retention time from Lim et al. (2008)

time to be converted by the microorganisms into the maximum potential VFA concentrations. As discussed in the introduction to this section, the low RTs might have resulted in a digestate that contained additional feed that could have still been utilized in the production of volatile fatty acids.

Wijekoon et al. (2011) (Table 3, Reference 1), found that a higher OLR yielded higher concentrations of VFAs. Tested at an OLR of 5,8 and, $12 \mathrm{~kg} \mathrm{COD} / \mathrm{m}^{3}$ day, Wijekoon saw the total VFA production was highest at an OLR of 12 with VFA concentrations around 7,000 mg/L. It is noted that although the concentrations of VFAs were higher, the removal efficiency of BOD and COD suffered significantly (Wijekoon, Visvanathan, \& Abeynayaka, 2011). At an OLR of 5, 8, and 12 , the respective removal efficiencies were around 75,81 , and $61 \%$. Although more feed is being supplied to the reactor, it is not being effectively transformed to VFAs. It can be seen 


\begin{tabular}{|c|c|c|c|c|c|}
\hline Ref. \# & Waste & OLR or RT & VFA Production & $\begin{array}{c}\text { Reactor } \\
\text { Configuration }\end{array}$ & Reference \\
\hline \multirow{3}{*}[1]{} & \multirow{3}{*}{$\begin{array}{c}\text { Molasses Based } \\
\text { Synthetic } \\
\text { Wastewater }\end{array}$} & $5 \mathrm{~kg} \mathrm{COD} / \mathrm{m}^{3}$ day & $2,500 \mathrm{mg} / \mathrm{L} *$ & \multirow{3}{*}{$\begin{array}{c}\text { Two Stage anaerobic } \\
\text { membrane } \\
\text { bioreactor }\end{array}$} & \multirow{3}{*}{$\begin{array}{c}\text { Wijekoon et al. } \\
\text { (2011) }\end{array}$} \\
\hline & & $8 \mathrm{~kg} \mathrm{COD} / \mathrm{m}^{3}$ day & $4,750 \mathrm{mg} / \mathrm{L}^{*}$ & & \\
\hline & & $12 \mathrm{~kg} C O D / \mathrm{m}^{3}$ day & $7,000 \mathrm{mg} / \mathrm{L}^{*}$ & & \\
\hline \multirow{2}{*}[2]{} & \multirow{2}{*}{ Industrial Waste } & 18 hours & $394 \mathrm{mg} / \mathrm{L}$ & \multirow{2}{*}{$\begin{array}{l}\text { Bench scale mixed } \\
\text { reactor }\end{array}$} & \multirow{2}{*}{$\begin{array}{c}\text { Banerjee et al. } \\
\text { (1998) }\end{array}$} \\
\hline & & 30 hours & $542 \mathrm{mg} / \mathrm{L}$ & & \\
\hline \multirow{6}{*}{ [3] } & \multirow{6}{*}{$\begin{array}{c}\text { Dairy } \\
\text { Wastewater }\end{array}$} & 12 hours & $1540 \mathrm{mg} \mathrm{d} / \mathrm{m}^{3} *$ & \multirow{6}{*}{$\begin{array}{l}\text { Lab scale continuous } \\
\text { flow anaerobic } \\
\text { reactor }\end{array}$} & \multirow{6}{*}{$\begin{array}{l}\text { Demirel et al. } \\
\qquad(2004)\end{array}$} \\
\hline & & 16 hours & $550 \mathrm{mg} \mathrm{d} / \mathrm{m}^{3} *$ & & \\
\hline & & & & & \\
\hline & & 18 hours & $200 \mathrm{mg} \mathrm{d} / \mathrm{m}^{3} *$ & & \\
\hline & & 20 hours & $180 \mathrm{mg} \mathrm{d} / \mathrm{m}^{3} *$ & & \\
\hline & & 22 hours & $140 \mathrm{mg} \mathrm{d} / \mathrm{m}^{3} *$ & & \\
\hline \multirow{3}{*}[4]{} & \multirow{3}{*}{ PS and WAS } & 5 days & $0.277 \mathrm{~g} / \mathrm{gVS}$ & \multirow{3}{*}{$\begin{array}{c}\text { Batch tests (glass } \\
\text { bottles) }\end{array}$} & \multirow{3}{*}{$\begin{array}{c}\text { Jankowsca et al. } \\
\text { (2015) }\end{array}$} \\
\hline & & 10 days & $0.420 \mathrm{~g} / \mathrm{gVS}$ & & \\
\hline & & 15 days & $0.621 \mathrm{~g} / \mathrm{gVS}$ & & \\
\hline \multirow{6}{*}[5]{} & \multirow{6}{*}{ Food Waste } & 4 days & $5.0-6.0 \mathrm{~g} / \mathrm{L}$ & \multirow{6}{*}{$\begin{array}{l}\text { Semi-continuous } \\
\text { mixed reactor }\end{array}$} & \multirow{6}{*}{ Lim et al. (2008) } \\
\hline & & 8 days & $13.0-14.0 \mathrm{~g} / \mathrm{L}$ & & \\
\hline & & 12 days & $20.5-22.0 \mathrm{~g} / \mathrm{L}$ & & \\
\hline & & $5 \mathrm{~g} / \mathrm{Ld}$ & $13.0-14.0 \mathrm{~g} / \mathrm{L}$ & & \\
\hline & & $9 \mathrm{~g} / \mathrm{Ld}$ & $23.0-24.0 \mathrm{~g} / \mathrm{L}$ & & \\
\hline & & $13 \mathrm{~g} / \mathrm{L} \mathrm{d}$ & $28.9-30.0 \mathrm{~g} / \mathrm{L}$ & & \\
\hline \multirow{3}{*}[6]{} & \multirow{3}{*}{$\begin{array}{l}\text { Cheese Whey } \\
\text { Permeate }\end{array}$} & 4 days & $6343 \mathrm{mg} \mathrm{COD} / \mathrm{L}$ & \multirow{3}{*}{$\begin{array}{l}\text { Anaerobic } \\
\text { Sequencing batch } \\
\text { reactor }\end{array}$} & \multirow{3}{*}{$\begin{array}{l}\text { Calero et al. } \\
\qquad(2018)\end{array}$} \\
\hline & & 6 days & $7698 \mathrm{mg}$ COD/L & & \\
\hline & & 10 days & $6347 \mathrm{mg}$ COD/L & & \\
\hline \multirow{4}{*}{ [7] } & \multirow{4}{*}{$\begin{array}{c}\text { Fruit and } \\
\text { Vegetable Waste }\end{array}$} & 1 day & $4400 \mathrm{mg} / \mathrm{L}$ & \multirow{4}{*}{$\begin{array}{l}\text { Continuously stirred } \\
\text { acidogenic reactor }\end{array}$} & \multirow{4}{*}{$\begin{array}{l}\text { Dinsdale et al. } \\
\qquad(2000)\end{array}$} \\
\hline & & 2 days & $6100 \mathrm{mg} / \mathrm{L}$ & & \\
\hline & & 3 days & $6150 \mathrm{mg} / \mathrm{L}$ & & \\
\hline & & 4 days & $6620 \mathrm{mg} / \mathrm{L}$ & & \\
\hline
\end{tabular}

Table 3: Compilation of studies effects of OLR and RT on VFA production. Note: Shaded values represent highest VFA concentrations for each study. VFA productions with an asterisk" * "are approximations taken from figures where exact values are not specified. 
that there is a significant loss in removal efficiency when moving from an OLR of 8 to 12. Therefore, although a larger OLR has the potential to yield higher VFA concentrations, it can also suffer when it comes to looking at removal efficiencies. The problem lies in determining an optimal OLR that produce the highest possible concentrations whilst also not yielding low removal efficiencies. This will allow for the most to be made out of the various waste streams that are utilized for the production of VFAs.

Demirel et al. (2004) (Reference 3) saw a direct relationship between RT with regards to VFA production. HRT ranges of 12 to 24 hours were examined with a max OLR reaching $9.3 \mathrm{~kg}$ $\mathrm{COD} / \mathrm{m}^{3}$ day. The maximum VFA concentration was found at the shortest RT tested of 12 hours. What is noted by Demirel er al. (2004) is that there are no significant increase in VFA concentrations from RTs of 22 to 18 hours. The pickup in VFA production is seen at 16 hours and an even larger increase in VFA production is seen moving to an RT of 12 hours (being the highest). It is reported that Demirel et al.'s (2004) results are consistent across other studies and literature. Larger VFA concentrations are seen at shorter RTs or larger OLRs as new feed is supplied more readily. Demirel et al. concludes that the HRT was the most influential parameter with regards to their VFA production showing it is an important operational parameter (Demirel \& Yenigun, 2004).

It has been seen that there is no one set retention time that is most optimal. What can be noted is that in many scenarios such as Reference $2,4,5$, and 7, the longer retention times in those individual studies outperformed the shorter retention times. The simple reason for this could be explained as the waste having more time to convert to VFAs as it was not replaced as soon as the shorter retention times. One study that saw different results was Reference 6, where the retention time of 6 days (between a low RT of 4 days and a high RT of 10 day) was the best performing RT. This scenario points to the fact that if the VFAs are left to sit for extended periods of time without 
being removed (such is the case in long RTs), the VFAs might convert to other products such as methane which is the case in classic anaerobic digestion for biogas production.

When it came time to looking at the impact of organic loading rate, Reference 1 and 5 pointed towards higher OLR as having the highest concentrations/production rates. This would mean that larger supplies of waste being supplied and removed more often would appear as having better VFA productions. However as was discussed in this section with regards to Reference 1, the conversion rates associated with larger OLRs can see the replacement of the waste stream before it has had the proper time to yield the maximum possible VFAs. This was discussed by Wijekoon et al. (2011) and saw that the removal efficiencies suffered as a result of these high OLRs. Although more VFAs were being produced within shorter periods of time, the waste was not being utilized to its maximum potential. As a result, this could be seen as a waste of resources as the waste streams are not being optimized to produce to their fullest potential.

All together, the effects of the Organic Loading Rate and Retention Time point to several important discussion points. Longer periods of time (higher RTs) allow for the waste to convert to more VFAs. However, if conditions are unfavorable, the long RTs can see loses of VFAs as they are converted to other products. Lastly there is the use of these waste streams to their maximum potential. The higher OLRs tended to have higher concentrations of VFAs (as more fresh feed is being fed to the reactor in shorter periods of time) however, this comes at a cost. If the waste is removed from the system prematurely, there is the possibility to see less efficient conversions and from the circular economy outlook, this is not as favorable. Each specific waste stream along with their respective properties need to be looked into in order to determine RTs/OLRs that are economically feasible whilst also looking to have favorable conversion rates in order to not waste the feeds that are able to supply value added products. 


\subsection{Effects of Substrate to Inoculum Ratio (Food to Microorganism)}

Two major components of anaerobic digestion and VFA production are the food and microorganisms which are utilized. Without one of these components the conversion process would be ineffective. As it is known in the anaerobic digestion process, microorganisms (also referred to as inoculum) see the breakdown and conversion of biodegradable material (the feed, also referred to as substrate). There are a variety of different combinations of food to microorganism $(\mathrm{F} / \mathrm{M})$ ratios that have varying effects on the production of volatile fatty acids. This section will specifically look at reported combinations of food (substrates) to microorganisms (inoculum) ratios and their effects on VFA production. Additionally, there will be some discussion of the effects of the food to microorganism ratio on inhibiting methanogenesis.

As discussed in section 2.2, methanogenesis can be inhibited by operating under unfavorable $\mathrm{pH}$ levels for methanogens. Similarly, the food to microorganism ratio has demonstrated this effect on the inhibition of the methanogenesis process as well. Zhou et al. (2011) studied the effects of varying substrate to inoculum (S/I) ratios ranging from $0.33-4.0$. It was found that optimum S/I ratios for the production of methane ranged form $0.6-0.9$ and that a decrease in methane production was experienced when the S/I ratio exceeded 1.0 (Zhou, et al., 2011). Zhou et al. (2011) explains that this inhibition was a result of the build up VFAs which in turn inhibited the fermentation process (Zhou, et al., 2011). This shows that the inhibition of methanogenesis can be achieved without needing to alter $\mathrm{pH}$ levels of the digestate which could prove costly and unfeasible in large scale applications as large amounts of chemicals would be required to alter $\mathrm{pH}$ levels (Guo, et al., 2014). Therefore, it is seen that the food to microorganism ratio has the potential to prevent methanogenesis (which in turn allows for VFA production to continue) whilst not requiring the $\mathrm{pH}$ to be altered. 
Xu et al. (2012) (Table 4, Reference 2) investigated the effect of the inoculum to substrate ratio (ISR) on the hydrolysis and acidification stage. As discussed in section 1.2, the hydrolysis and acidification stage are two major components to the formation of VFA production. Hydrolysis sees the breakdown of the waste into more soluble forms and the acidification stage sees the formation of VFAs such as butyric acid and propionic acid. Being able to increase the effectiveness of these early stages of anaerobic digestion could see increases to conversion rates and possibly save on the overall time needed for the waste to properly convert to VFAs. Xu et al. found mixed results on the overall effectiveness of the multiple ISRs tested. ISRs of $0 \%, 5 \%, 20 \%$, and $80 \%$ (weight per weight basis) are referenced as Substrate to Inoculum ratios (S/I ratios) of "No Inoculum", 20, 5, and 1.25 respectively in Table 4 . The higher ISRs of $20 \%$ and $80 \%$ found increased results with regards to their VFA production compared to 5\% and no inoculum with the $80 \%$ ISR (S/I of 1.25) having concentrations of $11.8 \mathrm{gCOD} / \mathrm{L} . \mathrm{Xu}$ et al. reported that an increasing ISR increased the decomposition in the liquefaction and acidification stages. It could be suggested that the 5\% and $0 \%$ ISRs do not provide enough inoculum to properly breakdown the food waste and as a result, their VFA production is substantially lower (6.30 and $6.20 \mathrm{gCOD} / \mathrm{L}$ respectively). Although the VFA production rates were higher for larger ISRs, the decomposition rate of the food waste was not changed significantly (Xu, Karthikeyan, Selvam, \& Wong, 2012). Overall, the ISR of $20 \%$ ( $\mathrm{S} / \mathrm{I}$ of 5 ) is recommended by $\mathrm{Xu}$ et al. due to it still performing well in the hydrolysis and acidification stage but also having good decomposition efficiencies (Xu, Karthikeyan, Selvam, \& Wong, 2012). While the higher ISR provided more VFA production capabilities, it did not decompose the food waste as effectively in the hydrolysis stage. It could also be seen that the significantly low ISR of 5\% (corresponding to a S/I of 20) had unfavorable VFA production 


\begin{tabular}{|c|c|c|c|c|c|}
\hline Ref. \# & Waste & $\begin{array}{c}\text { Substrate to Inoculum } \\
\text { Ratio (S/I) }\end{array}$ & VFA Production & Reactor Configuration & Reference \\
\hline \multirow{5}{*}{ [1] } & \multirow{5}{*}{ Food Waste } & 2 & $550 \mathrm{mg}$ COD / g VS * & \multirow{5}{*}{ Anaerobic reactors $(250 \mathrm{~mL})$} & \multirow{5}{*}{ Guo et al. (2014) } \\
\hline & & 4 & $751.20 \mathrm{mg}$ COD / g VS & & \\
\hline & & 6 & $967.12 \mathrm{mg}$ COD / g VS & & \\
\hline & & 8 & 375 mg COD / g VS * & & \\
\hline & & 10 & $220 \mathrm{mg}$ COD / g VS * & & \\
\hline \multirow{4}{*}{ [2] } & \multirow{4}{*}{$\begin{array}{l}\text { Artificial Food } \\
\text { Waste }\end{array}$} & No Inoculum & $6.20 \mathrm{~g} \operatorname{COD} / \mathrm{L}^{*}$ & \multirow{4}{*}{ Leach Bed Reactor } & \multirow{4}{*}{ Xu et al. (2012) } \\
\hline & & 20 & $6.30 \mathrm{~g} \operatorname{COD} / \mathrm{L}^{*}$ & & \\
\hline & & 5 & $7.8 \mathrm{~g} \operatorname{COD} / \mathrm{L}^{*}$ & & \\
\hline & & 1.25 & $11.8 \mathrm{~g}$ COD / L * & & \\
\hline \multirow{6}{*}{ [3] } & \multirow{6}{*}{ Food Waste } & 4 & $7000 \mathrm{mg} / \mathrm{L}^{*}$ & \multirow{6}{*}{$\begin{array}{l}\text { Batch Reactors \& Lab-Scale } \\
\text { Stirred Tank Reactor }\end{array}$} & \multirow{6}{*}{$\begin{array}{l}\text { Forester-Carneiro et al. } \\
\qquad(2008)\end{array}$} \\
\hline & & 2.33 & $5563 \mathrm{mg} / \mathrm{L}$ & & \\
\hline & & 4 & $6750 \mathrm{mg} / \mathrm{L}^{*}$ & & \\
\hline & & 2.33 & 5468 mg / L & & \\
\hline & & 4 & $4100 \mathrm{mg} / \mathrm{L}^{*}$ & & \\
\hline & & 2.33 & $3800 \mathrm{mg} / \mathrm{L} *$ & & \\
\hline \multirow{10}{*}{ [4] } & \multirow{5}{*}{$\begin{array}{l}\text { Food Waste (Low } \\
\text { LOF) }\end{array}$} & 0.33 & $0.55 \mathrm{~g} / \mathrm{L}^{*}$ & \multirow{10}{*}{ Glass Batch Reactors } & \multirow{10}{*}{ Kawai et al. (2014) } \\
\hline & & 0.5 & $1.05 \mathrm{~g} / \mathrm{L} *$ & & \\
\hline & & 1 & $2.65 \mathrm{~g} / \mathrm{L}^{*}$ & & \\
\hline & & 2 & $2.15 \mathrm{~g} / \mathrm{L}^{*}$ & & \\
\hline & & 4 & $2.5 \mathrm{~g} / \mathrm{L} *$ & & \\
\hline & \multirow{5}{*}{$\begin{array}{l}\text { Food Waste (High } \\
\text { LOF) }\end{array}$} & 0.33 & $2.0 \mathrm{~g} / \mathrm{L}^{*}$ & & \\
\hline & & 0.5 & $4.5 \mathrm{~g} / \mathrm{L}^{*}$ & & \\
\hline & & 1 & $3.65 \mathrm{~g} / \mathrm{L}^{*}$ & & \\
\hline & & 2 & $3.25 \mathrm{~g} / \mathrm{L}^{*}$ & & \\
\hline & & 4 & $3.0 \mathrm{~g} / \mathrm{L} *$ & & \\
\hline \multirow{6}{*}{ [5] } & \multirow{6}{*}{ Chlorella sp. } & 0.33 & $21.83 \mathrm{mmol} / \mathrm{L}$ & \multirow{6}{*}{ Serum Bottles } & \multirow{6}{*}{ Sun et al. (2011) } \\
\hline & & 0.5 & $28.00 \mathrm{mmol} / \mathrm{L}$ & & \\
\hline & & 1 & $38.30 \mathrm{mmol} / \mathrm{L}$ & & \\
\hline & & 1.25 & $41.21 \mathrm{mmol} / \mathrm{L}$ & & \\
\hline & & 2 & $61.92 \mathrm{mmol} / \mathrm{L}$ & & \\
\hline & & 3.33 & $65.07 \mathrm{mmol} / \mathrm{L}$ & & \\
\hline
\end{tabular}

Table 4: Compilation of studies effects of Substrate to Inoculum ratio (S/I) on VFA production. Note: Shaded values represent highest VFA concentrations for each study. VFA productions with an asterisk" * "are approximations taken from figures where exact values are not specified. 
compared to the ISRs with higher inoculum contents. This demonstrates something that may be explained with common sense, that being that the lack of sufficient inoculum led to low production of VFA concentrations. The lack of inoculum heavily deterred the breakdown of food waste into VFAs, therefore extremely high S/I ratios (i.e. a mixture with a lot of feed and little inoculum) can be seen as ineffective in the conversion of waste to VFAs. If an economic goal is in mind, a further analysis into costs associated with various ISRs would need to be reviewed/developed to determine optimal conditions for underutilization of food waste in order to produce the highest VFA concentrations. However, from the perspective of a circular economy, a better utilization and decomposition of the food waste while still producing respectable VFA concentrations would be a more ideal goal as it would make the most out of the waste stream.

With reference to Table 4, Reference 4, specifically the food waste with low LOF (Labile

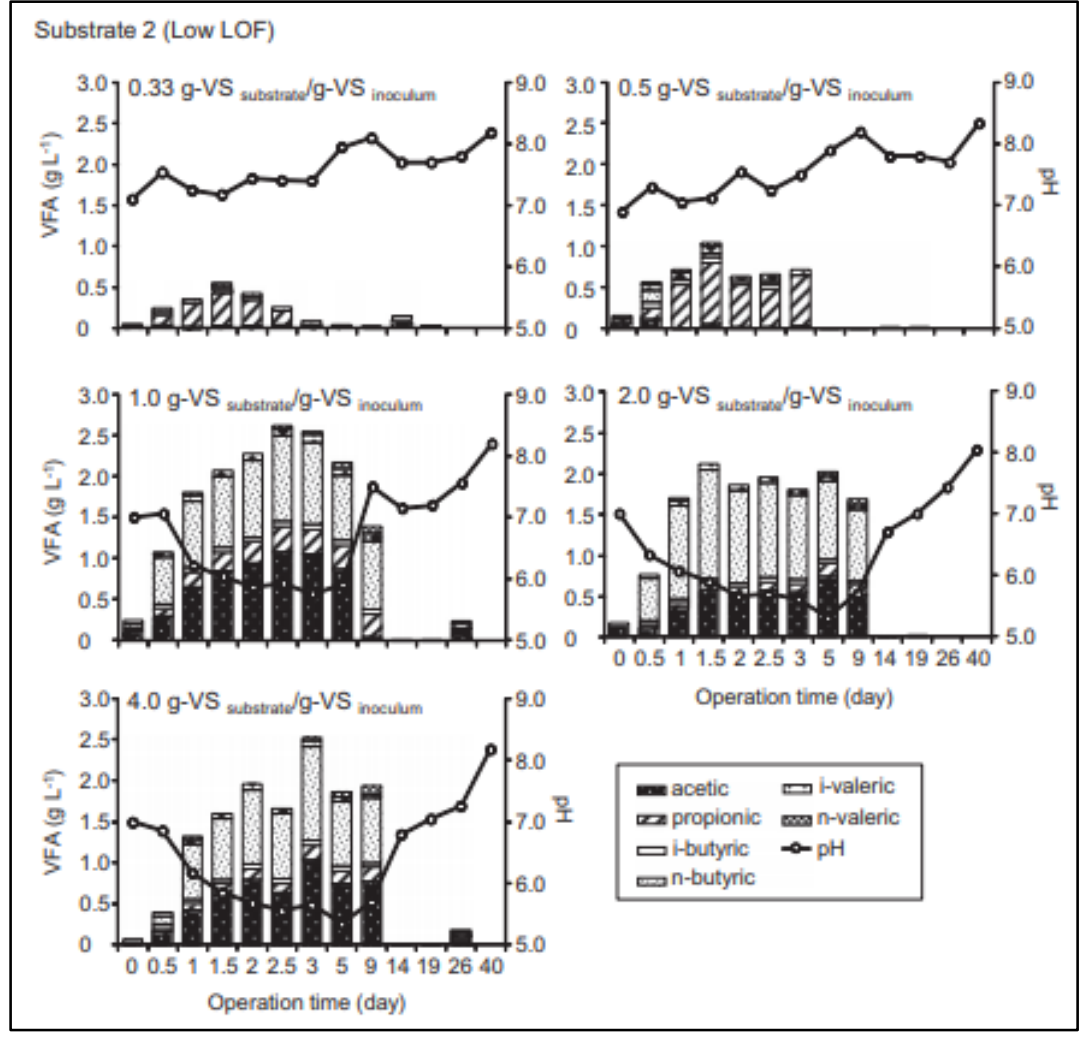

Figure 6: VFA Production for low LOF at S/I ratios ranging from 0.33 - 4.0 from Kawai et al. (Kawai, et al., 2014). organic fraction), the results of Kawai et al. (2014) will be discussed. The effect of the LOF and the $\mathrm{S} / \mathrm{I}$ ratios were the primary points of interest for this study. Kawai et al. (2014) assessed the effects of $\mathrm{S} / \mathrm{I}$ ratios of $0.33,0.5,1.0,2.0$ and 4.0 with the following VFA productions as seen in Figure 6. It can be seen that the $\mathrm{S} / \mathrm{I}$ ratios that are 1.0 and above have 
significantly higher VFA productions. Additionally, the low LOF content waste outperformed the high LOF content waste (not pictured in Figure 6) at all S/I ratios with respect to their VFA concentrations. Also seen in Figure 6 is the corresponding $\mathrm{pH}$ for the various S/I ratios. It can be noted that the $\mathrm{pH}$ of the high VFA producing S/I ratios of 1.0, 2.0 and 4.0 are within ranges that are not optimal for methanogenesis stage of anaerobic digestion generally being around or below a pH of 6 for the high VFA producing regions (Kawai, et al., 2014). The regions with high VFA concentrations can be attributed to a combination of optimal S/I ratios on top of $\mathrm{pH}$ values that inhibit methanogenesis (Kawai, et al., 2014). Another result of interest from Kawai et al. (2014) were the methane yields associated with each tested S/I ratio. The 0.33 and $0.5 \mathrm{~S} / \mathrm{I}$ ratios for both high and low LOF produced the highest methane yields of all five tested S/I ratios. Therefore, it can be seen that these S/I ratios are not as optimal for VFA production as they result in greater methane production making them less suitable for VFA production.

Of the multiple studies looked at, substrate to inoculum ratios of above 1 tended to result in higher producing VFA concentrations. The one scenario where a S/I ratio was below 1 (Kawai et al (2014), Reference 4, High LOF) where a S/I ratio of 0.5 was the highest producer resulted in the most methane production (not pictured). Thus, it could be said that this S/I ratio might not be optimal as the end product being produced were not VFAs, but rather biogas/methane. However, as seen in sources such as Reference 1; Guo et al. (2014), too large of a S/I ratio sees loses of VFA concentrations as after a S/I ratio of 6, VFA production drops at S/I ratios of 8 and 10. This shows that too much substrate provided to the system cannot be effectively processed by inoculum and thus proves to be ineffective. Overall, S/I ratios ranging from 1 to 6 have shown to produce respectable VFAs whilst avoiding problems seen at overly high or too low of a S/I ratio. 


\subsection{Effects of Inhibitors}

\subsubsection{Inhibition of VFA production}

The process of anaerobic digestion for the formation of biogas and methane is one that is understood, and successful results have been produced because of this. Taking this well understood process and attempting to optimize it for VFA production can lead to challenges as the optimal conditions desired for the production of biogas/methane are not the same as for VFAs. Therefore, there are certain elements of the anaerobic digestion process that have the possibility to inhibit the formation of the desired VFAs. The process and its operating conditions are not the only things that have the possibility to inhibit VFA production. There are also additives or the presence of specific substances that have an inhibiting effect as well.

One such example of VFA inhibition is seen in Cysneiros et al. (2012) (Table 5, Reference 1). One of the goals of their research was to investigate the effect of $\mathrm{pH}$ control on the hydrolysis stage of anaerobic digestion. In the study, two scenarios were tested, one reactor was buffered for $\mathrm{pH}$ control while the other reactor was not. The buffered reactor saw a higher cumulative VFA production rate when compared to the unbuffered reactor. Cysneiros et al. (2012) goes on to comment that the unbuffered reactor was inhibited during the hydrolysis and acidogenesis stages which are evident through a figure in their research showing a slow rise in VFA accumulation at the beginning of the process when compared to the buffered reactor (Cysneiros, Banks, Heaven, $\&$ Karatzas, 2012). It is also mentioned that the unbuffered reactor also experienced low pH due to the lack of $\mathrm{pH}$ control. As a result of this low $\mathrm{pH}$, acidogenic bacteria which can normally operate outside of their optimum conditions suffered due to the $\mathrm{pH}$ being much lower $\mathrm{pH}$ around 4) and a result of this was seen in the form of lower acetic acid being produced (Cysneiros, Banks, Heaven, \& Karatzas, 2012). This demonstrates that a lack of $\mathrm{pH}$ control, or low $\mathrm{pH}$ in general has 
the ability to affect VFA production and can also inhibit specific concentrations of VFAs being formed.

Another example of inhibitory properties on VFA production was found in the substrate used. Feng et al. (2009) (Table 5, Reference 4) saw that low carbon to nitrogen ratios led to VFA production of less desired VFAs being produced. The more desired propionic acid (due to its use in Enhanced biological phosphorus removal) was produced less readily and acetic acid was produced instead (Feng, Chen, \& Zheng, 2009). This was combated by the addition of carbohydrates in the form of rice which raised the Carbon to Nitrogen $(\mathrm{C} / \mathrm{N})$ ratio. This demonstrates that the wastes properties were not ideal initially. Similar to the concept of codigestion discussed in section 1.3, the addition of carbon rich material aided in reversing this inhibitory characteristic.

\begin{tabular}{|c|c|c|c|c|c|}
\hline $\begin{array}{c}\text { Ref. } \\
\#\end{array}$ & Inhibitor & Brief Description & Waste & $\begin{array}{c}\text { Reactor } \\
\text { Configuration }\end{array}$ & Reference \\
\hline$[1]$ & $\begin{array}{c}\text { Unbuffered } \\
\text { Reactor / low } \\
\mathrm{pH} \\
\end{array}$ & $\begin{array}{c}\text { Lower VFA yields, especially } \\
\text { seen in the concentration of } \\
\text { acetic acid. }\end{array}$ & $\begin{array}{l}\text { Whole Crop } \\
\text { of Maize }\end{array}$ & $\begin{array}{l}\text { Leach bed } \\
\text { reactor }\end{array}$ & $\begin{array}{c}\text { Cysneiros et al. } \\
\text { (2012) }\end{array}$ \\
\hline$[2]$ & $\begin{array}{c}\text { Hydrogen } \\
\text { Sulfide }\left(\mathrm{H}_{2} \mathrm{~S}\right)\end{array}$ & $\begin{array}{c}\text { Inhibition of acetate } \\
\text { utilization. }\end{array}$ & $\begin{array}{l}\text { High sulfate } \\
\text { wastes }\end{array}$ & Glass syringes & $\begin{array}{l}\text { Hilton et al. } \\
\text { (1988) }\end{array}$ \\
\hline [3] & $\begin{array}{c}\text { Toxic } \\
\text { Reagents }\end{array}$ & $\begin{array}{c}\text { Decline in the concentration } \\
\text { of acetic and butyric acid } \\
\text { with increasing toxic } \\
\text { concentrations. }\end{array}$ & $\begin{array}{l}\text { Commercial } \\
\text { inoculum }\end{array}$ & $\begin{array}{l}\text { Glass serum } \\
\text { bottles }\end{array}$ & $\begin{array}{l}\text { Playne et al. } \\
\text { (1983) }\end{array}$ \\
\hline$[4]$ & $\begin{array}{l}\text { High Protein } \\
\text { Content \& } \\
\text { Low Carbon } \\
\text { to Nitrogen } \\
\text { ratio }(\mathrm{C} / \mathrm{N})\end{array}$ & $\begin{array}{l}\text { Production of propionic acid } \\
\text { was limited. }\end{array}$ & $\begin{array}{l}\text { Waste } \\
\text { activated } \\
\text { sludge }\end{array}$ & $\begin{array}{l}\text { Plexiglass } \\
\text { reactor }\end{array}$ & $\begin{array}{l}\text { Feng et al. } \\
\text { (2009) }\end{array}$ \\
\hline$[5]$ & Ammonia & $\begin{array}{l}\text { Ammonia lead to the } \\
\text { buildup of VFAs which } \\
\text { inhibited methanogenesis }\end{array}$ & - & - & $\begin{array}{l}\text { Rajagopal et } \\
\text { al. (2013) }\end{array}$ \\
\hline
\end{tabular}

Table 5: Inhibitory characteristics/conditions in the formations of VFAs and Methane 


\subsubsection{Inhibition of Methane}

The inhibition of VFA production is one that should be avoided when possible if the goal of anaerobic digestion is for the production of VFAs. As mentioned in section 1.2, the final phase of classic anaerobic digestion for the production of methane is methanogenesis. The inhibition of methanogenesis would be of interest for VFA production as this would eliminate or severely diminish the conversion of VFAs into methane and leave higher concentrations of VFAs to be extracted. Ideas of methane inhibition were discussed to some degree in section 2.2 where the avoidance of optimal $\mathrm{pH}$ regions for methanogenesis would be avoided. This did have positive results as seen in Figure 3 from Jankowsca et al. (2015) when suboptimal $\mathrm{pH}$ regions for methanogenesis were tested. Therefore, the inhibition of methane formation through the characteristics of the reactor have proven to be successful means to reduce methane and promote VFA formation.

Discussed in Rajagopal et al. (2013), the inhibition of methanogenesis through the presence of excess ammonia is a frequent problem seen in anaerobic digestion for the production of methane/biogas. However, in the case of VFA production, this problem can be viewed as a solution. Excess or high concentrations of ammonia is reported to cause decreases in microbial activities (Rajagopal, Masse, \& Singh, 2013). This occurs as VFAs that are formed buildup and methane production begins to decrease. This is a double victory for VFA production as high VFA concentrations form while at the same time, methane production is halted. This is a topic discussed in many literatures as a problem for anaerobic digestion but with regards to VFA production, it can be a useful tool which helps to reduce VFA conversion into methane. 


\section{Conclusion}

Returning back to the idea of a circular economy discussed in the introduction, a better understanding and use of the resources that society has at hand is vital in order to continue its use at the current rate. If reuse and repurposing of waste streams are not considered, trouble can arise in the form of lack of resources. Although society is not at the point where resources are scarce and hard to find, this can become a problem for future generations to face if it is not dealt with in the present. There is no need for catastrophe to be the driving factor as to why humanity needs to become more suited to resource management. Therefore, the research and investigation into things viewed as waste are important in providing use to things that are viewed as unusable.

This paper reviewed the topic of VFA production and the conditions that affect it. The anaerobic digestion process is well known and utilized in the production of methane and biogas. Utilizing this well-known technology and altering its parameters to better suit VFA production as an end product is something that can provide great things for society. Firstly, this allows for waste streams that may not be suitable for biogas and methane production to be looked at to determine if they may be suitable for VFA production. Where traditional anaerobic digestion would have seen these wastes as suboptimal, VFA production could shed new light into the usefulness of them. Additionally, having another end product from these waste streams would provide a competitive marketplace as the waste could be seen as a more valuable product due to its variety of uses.

The operating conditions discussed in this paper included the $\mathrm{pH}$, temperature, Organic loading rate (OLR) / retention time (RT), substrate to inoculum ratio (S/I), and the effects of inhibitors. The effect of $\mathrm{pH}$ saw the inhibition of methanogenesis at suboptimal $\mathrm{pHs}$ for methanogens. This allows for VFAs to be produced in higher concentrations as they are not converted to VFAs as in standard anaerobic digestion processes. Next, the effects of temperature 
saw the formation of different VFAs dependant on temperature ranges, specifically mesophilic and thermophilic conditions. The variation in VFAs produced at these different temperatures is useful as it can allow for the targeting of certain VFAs to be produced. If the market value of these VFAs was to be looked into, ideal temperature ranges could be used to target production of specific VFAs with the most valuable or sought-after ones being produced. However, this is outside the scope of this paper. Next the effect of OLR and RT were examined. Overall, more retention time allowed for higher concentrations of VFAs to be reached and maximized the potential of the waste stream. However, steadily supplying more waste (higher OLR) allowed for more VFAs to be produced immediately but saw less use out of the waste stream as it was not given sufficient time to convert into VFAs. This is an important factor with regards to the circular economy as getting the most out of a waste stream would be the ideal goal but at the same time, it must also be a practical and financially feasible. Therefore, a careful look into optimal OLRs and RTs would need to be carried out in order to ensure the most is being made from the waste whilst also not putting operations into jeopardy. S/I ratios above 1 saw that sufficient inoculum (microorganisms) was supplied to the waste stream in order to effectively convert it into VFAs. However, care must be put into ensuring that excessively high ratios are not used as this could lead to inefficiencies in the process as there would be too many microorganisms and no waste for them to convert. Lastly, inhibitors of VFAs and the methanogenesis process were looked at. In any field, there are things that can negatively impact production and they should be avoided in order to ensure efficiency and maximize the potential production from the waste streams.

In conclusion, VFA production and the conditions that affect it should continue to be investigated to aid in the efficient conversion of waste streams into valuable VFAs. This will allow for the circular economy to flourish as the most will be made out of the resources at hand. 


\section{References}

Atasoy, M., Owusu-Agyeman, I., Plaza, E., \& Cetecioglu, Z. (2018). Bio-based volatile fatty acid production and recovery from waste streams: Current status and future challenges. Bioresource technology.

Banerjee, A., Elefsiniotis, P., \& Tuhtar, D. (1998). Effect of HRT and temperature on the acidogenesis of municipal primary sludge and industrial wastewater. \{Water science and technology, 417-423.

Brody, T. (1998). Nutritional biochemistry. Elsevier.

Calero, R. R., Lagoa-Costa, B., Fernandez-Feal, M. M., Kennes, C., \& Veiga, M. C. (2018). Volatile fatty acids production from cheese whey: influence of $\mathrm{pH}$, solid retention time and organic loading rate. Journal of Chemical Technology \& Biotechnology, 1742-1747.

Chen, Y., Jiang, X., Xiao, K., Shen, N., Zeng, R. J., \& Zhou, Y. (2017). Enhanced volatile fatty acids (VFAs) production in a thermophilic fermenter with stepwise $\mathrm{pH}$ increase--Investigation on dissolved organic matter transformation and microbial community shift. Water research, 261-268.

Clifford, C. B. (2018). Alternative Fuels from Biomass Sources 12.1 Anaerobic Digestion. Retrieved from Penn State e-Education Institute: https://www.e-education.psu.edu/egee439/node/727

Cysneiros, D., Banks, C. J., Heaven, S., \& Karatzas, K.-A. G. (2012). The effect of pH control and 'hydraulic flush'on hydrolysis and Volatile Fatty Acids (VFA) production and profile in anaerobic leach bed reactors digesting a high solids content substrate. Bioresource technology, 263-271.

Demirel, B., \& Yenigun, O. (2004). Anaerobic acidogenesis of dairy wastewater: the effects of variations in hydraulic retention time with no pH control. Journal of Chemical Technology \& Biotechnology, 755-760.

Dinsdale, R., Premier, G., Hawkes, F., \& Hawkes, D. (2000). Two-stage anaerobic co-digestion of waste activated sludge and fruit/vegetable waste using inclined tubular digesters. Bioresource technology, 159-168.

Eddy, B., \& Metcalf. (1979). Wastewater engineering : treatment, disposal, reuse. McGraw-Hill.

Esteban-Gutierrez, M., Garcia-Aguirre, J., Irizar, I., \& Aymerich, E. (2018). From sewage sludge and agrifood waste to VFA: Individual acid production potential and up-scaling. Waste management, 203-212.

Fang, W., Ye, J., Zhang, P., Zhu, X., \& Zhou, S. (2017). Solid-state anaerobic fermentation of spent mushroom compost for volatile fatty acids production by $\mathrm{pH}$ regulation. International Journal of Hydrogen Energy, 18295-18300.

Feng, L., Chen, Y., \& Zheng, X. (2009). Enhancement of waste activated sludge protein conversion and volatile fatty acids accumulation during waste activated sludge anaerobic fermentation by carbohydrate substrate addition: the effect of $\mathrm{pH}$. Environmental science \& technology, 43734380 . 
Forster-Carneiro, T., Perez, M., \& Romero, L. (2008). Influence of total solid and inoculum contents on performance of anaerobic reactors treating food waste. Bioresource technology, 6994-7002.

Guo, W., Wu, Q., Yang, S., Luo, H., Peng, S., \& Ren, N. (2014). Optimization of ultrasonic pretreatment and substrate/inoculum ratio to enhance hydrolysis and volatile fatty acid production from food waste. Rsc Advances, 53321-53326.

Hao, J., \& Wang, H. (2015). Volatile fatty acids productions by mesophilic and thermophilic sludge fermentation: biological responses to fermentation temperature. Bioresource technology, 367373.

He, M., Sun, Y., Zou, D., Yuan, H., Zhu, B., Li, X., \& Pang, Y. (2012). Influence of temperature on hydrolysis acidification of food waste. Procedia Environmental Sciences, 85-94.

Hilton, B. L., \& Oleszkiewicz, J. A. (1988). Sulfide-induced inhibition of anaerobic digestion. Journal of environmental engineering, 1377-1391.

Jankowska, E., Chwialkowska, J., Stodolny, M., \& Oleskowicz-Popiel, P. (2015). Effect of pH and retention time on volatile fatty acids production during mixed culture fermentation. Bioresource technology, 274-280.

Jiang, J., Zhang, Y., Li, K., Wang, Q., Gong, C., \& Li, M. (2013). Volatile fatty acids production from food waste: effects of $\mathrm{pH}$, temperature, and organic loading rate. Bioresource technology, 525-530.

Kawai, M., Nagao, N., Tajima, N., Niwa, C., Matsuyama, T., \& Toda, T. (2014). The effect of the labile organic fraction in food waste and the substrate/inoculum ratio on anaerobic digestion for a reliable methane yield. Bioresource technology, 174-180.

Kim, M., Ahn, Y.-H., \& Speece, R. (2002). Comparative process stability and efficiency of anaerobic digestion; mesophilic vs. thermophilic . Water research, 4369-4385.

Kim, M., Gomec, C. Y., Ahn, Y., \& Speece, R. (2003). Hydrolysis and acidogenesis of particulate organic material in mesophilic and thermophilic anaerobic digestion. Environmental technology, 11831190.

Lim, S.-J., Kim, B. J., Jeong, C.-M., Ahn, Y. H., Chang, H. N., \& others. (2008). Anaerobic organic acid production of food waste in once-a-day feeding and drawing-off bioreactor. Bioresource Technology, 7866-7874.

Liu, H., Wang, J., Liu, X., Fu, B., Chen, J., \& Yu, H.-Q. (2012). Acidogenic fermentation of proteinaceous sewage sludge: effect of $\mathrm{pH}$. Water research, 799-807.

Maharaj, I., \& Elefsiniotis, P. (2001). The role of HRT and low temperature on the acid-phase anaerobic digestion of municipal and industrial wastewaters. Bioresource technology, 191-197.

Nielsen, H. B., \& Ahring, B. K. (2006). CONTROL PARAMETERS FOR UNDERSTANDING AND PREVENTING PROCESS IMBALANCES IN BIOGAS PLANTS. EMPHAS IS ON VFA DYNAMICS. Technical University of Denmark (DTU).

Playne, M., \& Smith, B. (1983). Toxicity of organic extraction reagents to anaerobic bacteria. Biotechnology and bioengineering, 1251-1265. 
Rajagopal, R., Masse, D. I., \& Singh, G. (2013). A critical review on inhibition of anaerobic digestion process by excess ammonia. Bioresource technology, 632-641.

Recycling Council of Ontario. (2019). Circular Economy. Retrieved from Recycling Council of Ontario: https://rco.on.ca/circular-economy/

Sun, J., Yuan, X., Shi, X., Chu, C., Guo, R., \& Kong, H. (2011). Fermentation of Chlorella sp. for anaerobic bio-hydrogen production: influences of inoculum--substrate ratio, volatile fatty acids and NADH. Bioresource technology, 10480-10485.

Tamis, J., Joosse, B., Loosdrecht, M. v., \& Kleerebezem, R. (2015). High-rate volatile fatty acid (VFA) production by a granular sludge process at low pH. Biotechnology and bioengineering, 22482255.

Wang, K., Yin, J., Shen, D., \& Li, N. (2014). Anaerobic digestion of food waste for volatile fatty acids (VFAs) production with different types of inoculum: effect of $\mathrm{pH}$. Bioresource technology, 395401.

Wijekoon, K. C., Visvanathan, C., \& Abeynayaka, A. (2011). Effect of organic loading rate on VFA production, organic matter removal and microbial activity of a two-stage thermophilic anaerobic membrane bioreactor. Bioresource Technology, 5353-5360.

Xu, S. Y., Karthikeyan, O. P., Selvam, A., \& Wong, J. W. (2012). Effect of inoculum to substrate ratio on the hydrolysis and acidification of food waste in leach bed reactor. Bioresource technology, 425430.

Yan, B. H., Selvam, A., Xu, S. Y., \& Wong, J. W. (2014). A novel way to utilize hydrogen and carbon dioxide in acidogenic reactor through homoacetogenesis. Bioresource technology, 249-257.

Yuan, Q., Sparling, R., \& Oleszkiewicz, J. (2011). VFA generation from waste activated sludge: effect of temperature and mixing. Chemosphere, 6-3-607.

Zhang, P., Chen, Y., \& Zhou, Q. (2009). Waste activated sludge hydrolysis and short-chain fatty acids accumulation under mesophilic and thermophilic conditions: effect of $\mathrm{pH}$. Water research, 37353742.

Zhou, M., Yan, B., Wong, J. W., \& Zhang, Y. (2018). Enhanced volatile fatty acids production from anaerobic fermentation of food waste: a mini-review focusing on acidogenic metabolic pathways. Bioresource technology, 68-78.

Zhou, Y., Zhang, Z., Nakamoto, T., Li, Y., Yang, Y., Utsumi, M., \& Sugiura, N. (2011). Influence of substrate-to-inoculum ratio on the batch anaerobic digestion of bean curd refuse-okara under mesophilic conditions. Biomass and Bioenergy, 3251-3256.

Zhu, H., Parker, W., Basnar, R., Proracki, A., Falletta, P., Beland, M., \& Seto, P. (2008). Biohydrogen production by anaerobic co-digestion of municipal food waste and sewage sludges. International Journal of Hydrogen Energy, 3651-3659. 